\title{
Polycladida (Platyhelminthes, Rhabditophora) from Cape Verde and related regions of Macaronesia
}

\author{
Daniel CUADRADO ${ }^{1}$, Jorge RODRÍGUEZ ${ }^{2}$, Leopoldo MORO ${ }^{3}$, \\ Cristina GRANDE ${ }^{4} \&$ Carolina NOREÑA ${ }^{5, *}$ \\ ${ }^{1,5}$ Departmento de Biodiversidad y Biología Evolutiva, Museo Nacional de Ciencias Naturales (CSIC), \\ c/ José Gutiérrez Abascal 2, 28006 Madrid, Spain. \\ ${ }^{2}$ Marine Invertebrates Department, Australian Museum Research Institute, Australian Museum, 1 \\ William Street, Sydney, NSW 2010, Australia. \\ ${ }^{3}$ Servicio de Biodiversidad, Gobierno de Canarias, Edif. Usos Múltiples I, Av. Anaga n 35, Pl. 11, \\ 38071 S/C de Tenerife, Canary Islands, Spain. \\ ${ }^{4}$ Departamento de Biología, Facultad de Ciencias, Universidad Autónoma de Madrid, \\ Cantoblanco, 28049 Madrid, Spain. \\ "Corresponding author: norena@mncn.csic.es \\ ${ }^{1}$ Email: cuadradopm@hotmail.com \\ 2Email: jorge.rodriguezmonter@austmus.gov.au \\ ${ }^{3}$ Email: 1moraba@gobernodecanarias.org \\ ${ }^{4}$ Email: cristina.grande@uam.es \\ ${ }^{1}$ urn:lsid:zoobank.org:author:F0C14D94-9996-4A20-9D56-B02DDA1A78CA
${ }^{2}$ urn:1sid:zoobank.org:author:B833502E-CBA4-40CA-AE5A-BAD02F539062
${ }^{3}$ urn:1sid:zoobank.org:author:B66DDDE6-98E6-42FD-8E58-A1DF6A386BE5
${ }^{4}$ urn:1sid:zoobank.org:author:C8634A50-D3EC-467A-A868-225C231B40F2
${ }^{5}$ urn:lsid:zoobank.org:author:DD03B71F-B45E-402B-BA32-BB30343E0D95
}

\begin{abstract}
The systematics and distribution of the order Polycladida within the Macaronesian archipelagos are analysed. New species (Marcusia alba sp. nov., Prostheceraeus crisostomum sp. nov., Parviplana sodade sp. nov., Euplana claridade sp. nov., Stylochus salis sp. nov. and Distylochus fundae sp. nov.), new variety (Pseudoceros rawlinsonae var. galaxy), new records and records of shared species among different archipelagos are studied to compare the marine flatworm biodiversity of each island. The complex of archipelagos known as Macaronesia (including Madeira, Selvagens Islands, Canary Islands, Azores and Cape Verde) share a volcanic origin and European political influence. The five archipelagos are located along the eastern coast of the Atlantic Ocean and are subject to similar trade winds, streams (like the Gulf Stream) and cold currents. The term Macaronesia has suffered several changes throughout the years and it still is a topic of discussion in present times. The new delimitation of Macaronesia is mainly based on systematic studies on the invertebrate fauna of the islands. The resulting analyses shed new light on the differences and similarities among these archipelagos. In addition, molecular analyses employing $28 \mathrm{~S}$ nuclear gene sequences are compared to verify relationships among anatomically similar species of marine polyclads.
\end{abstract}


Keywords. Flatworms, distribution, Acotylea, Cotylea, 28S.

Cuadrado D., Rodríguez J., Moro L., Grande C. \& Noreña C. 2021. Polycladida (Platyhelminthes, Rhabditophora) from Cape Verde and related regions of Macaronesia. European Journal of Taxonomy 736: 1-43.

https://doi.org/10.5852/ejt.2021.736.1249

\section{Introduction}

From a political and biogeographic point of view, the complex of archipelagos known as Macaronesia is a mosaic of ecological and political factors, with two common denominators. One is that they are of volcanic origin and the other is that they are mostly European. Azores, Madeira and Selvagens Islands are Portuguese, the Canary Islands Spanish and Cape Verde independent, but with great European influence.

The five archipelagos are located along the eastern region of the Atlantic Ocean between latitude $15^{\circ} \mathrm{N}$ (Cape Verde) and $40^{\circ} \mathrm{N}$ (Azores) (Fig. 1) and are influenced by trade winds, the eastern branch of the Gulf Stream and the cold currents of the Canary Islands. Nonetheless, the biogeographic limits and definition of Macaronesia have undergone several changes over the years. Sunding (1979) included as part of Macaronesia a land strip ranging from Agadir (Morocco) to South Western Sahara (northern coast of the African continent), the so-called Macaronesian continental enclave. Sunding's inclusion of North Africa was the last addition to Macaronesia.

According to De Nicolas et al. (1989), Cape Verde belongs to Macaronesia due to its volcanic origin, but the presence of coral barriers, a tropical climate and specific vegetation make this archipelago notably different. Nonetheless, Kunkel (1993) subdivided Macaronesia into three subregions including Cape Verde: 1. Great Macaronesia ("Gross-Makaronesien"), which comprises the five archipelagos and the African and Iberian continental enclaves; 2. Central Macaronesia with Madeira, Selvagens Islands and Canary Islands and 3. Lauri-Macaronesia including Madeira, Selvagens Island, Canary Islands, Azores and the southwest region of Portugal (Algarve) (Fig. 1D), where some subregions overlap.

Médail \& Quézel (1999), after an exhaustive study on the vegetation of southwestern Morocco and the Canary Islands, concluded that North Africa should not be part of Macaronesia and included it in the Mediterranean region as the Agadirense province (Galán de Mera et al. 2003) or Agadiro-Ifniense region (Rivas-Martínez 2009; Salas \& Naranjo 2015).

Macaronesia should be included in the Mediterranean hotspot as both biogeographical regions share similar fauna, flora and climatology (Myers et al. 2000). In recent studies (Spalding et al. 2007), two marine ecoregions were established in relation to Macaronesia, namely the Lusitanian-Macaronesia region, formed by the archipelagos of Azores, Madeira, Selvagens Islands and Canary Islands, and the West African Transition region, which only includes Cape Verde. These considerations are shared also by Freitas et al. (2019) who proposes that Cape Verde must be considered a unique biogeographic region not included in the Macaronesia complex.

Today, most scientists accept that the term 'Macaronesia s. str.' is no longer valid as a biogeographical concept (Salas \& Naranjo 2015), but some archipelagos have conserved the Macaronesian idea: Madeira, Selvagens Islands and Canary Islands are considered 'Eumacaronesia' (Fig. 1) within the CanaryMadeira sub-region (Rivas-Martínez 2009) or 'Webbnesia' after Freitas et al. (2019).

In the past as well as today, the interest on these archipelagos remains due to their ecological conditions and its strategic position along marine routes. However, some islands are much better studied and explored than others. The best known, geologically and biologically, are the Canary Islands, Cape Verde and Madeira, followed by the Azores. Selvagens Islands are practically unknown. 
In the present study, the systematics and distribution of the Polycladida Lang, 1881 order within this archipelagos complex are analysed. New species, new records and records of shared species are considered to study the biodiversity between the archipelagos. The Macaronesian polyclad species are mainly known from the detailed studies conducted by Plehn $(1896)$ and Laidlaw $(1903,1906)$ in Cape Verde and the Azores. According to Laidlaw (1906), the species of Cape Verde have a markedly Mediterranean character, but it should be noted that not all the regions and coasts bathed by the Atlantic waters are known.

Additionally, the morphological results were studied alongside the analyses of the $28 \mathrm{~S}$ nuclear gene to verify relationships among anatomically similar and/or similarly distributed species (Table 1).

In summary, new concepts of the Macaronesia are based mainly in systematic studies on the invertebrate fauna (echinoderms, molluscs, decapod crustaceans, or polychaete annelids), fishes and algae of the islands. The present study on the systematics and distribution of the order Polycladida sheds new light

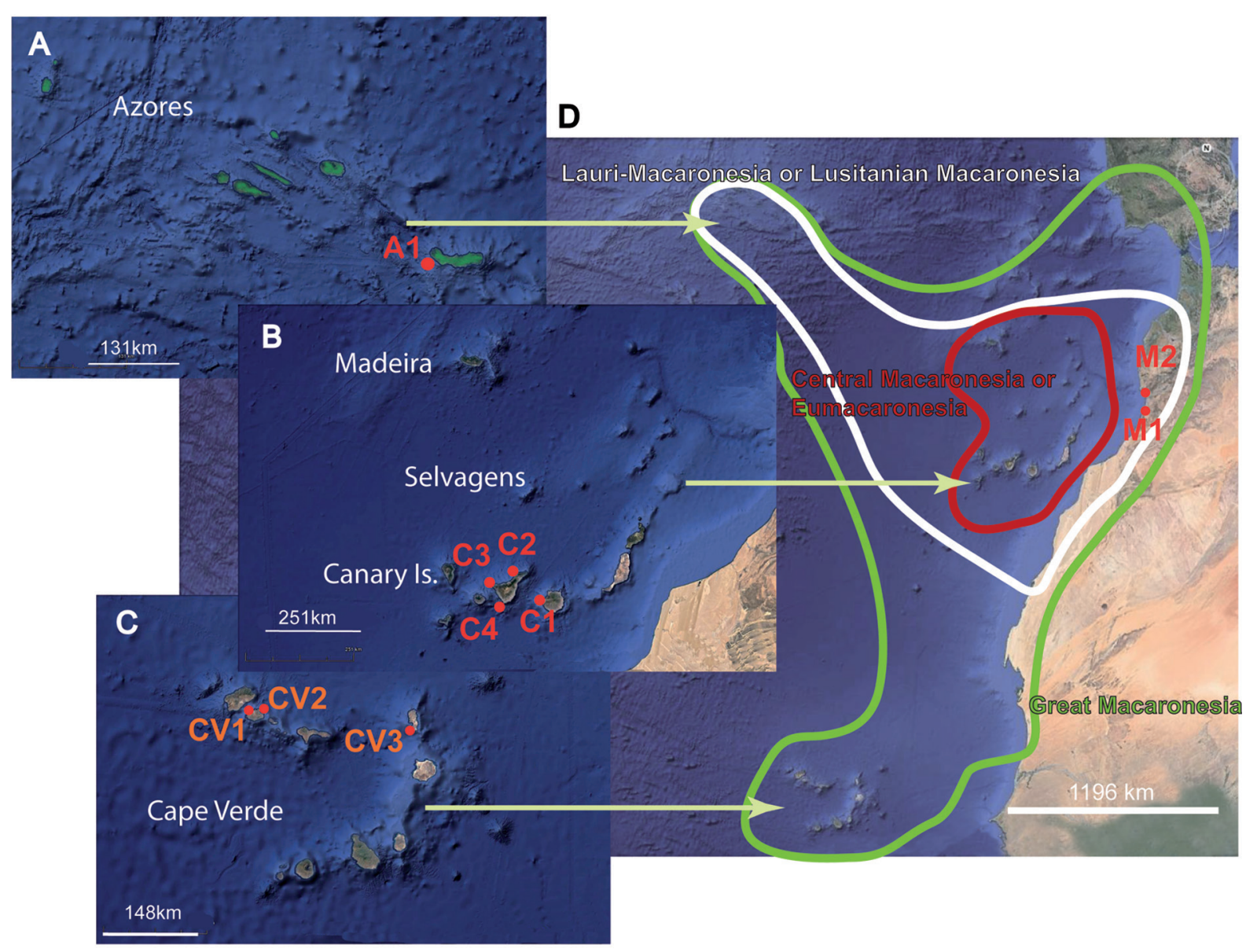

Fig. 1. Location of sampling points, distribution of the Macaronesian archipelagos and limitation of regions: Lauri-Macaronesia or Lusitanian Macaronesia (white); Central Macaronesia or Eumacaronesia (bordeaux) and Great Macaronesia (green). Abbreviations: A1 = San Miguel Island, Azores; C1 = Pasito Blanco, Gran Canaria, Canary Islands; C2 = Tenerife, Canary Islands; C $3=$ Garachico, Tenerife, Canary Islands; C4 = Amarilla Golf, Tenerife, Canary Islands; CV1 = Astillero Mindelo, São Vicente Island, Cape Verde; CV2 = Bahía das Gatas, São Vicente Island, Cape Verde; CV3 = Calheta Funda, Sal Island, Cape Verde; M1 = Ifni, South Morocco; M2 = Agadir, South Morocco. 
Table 1 (continued on next three pages). Species, localities and accession numbers of the material studied in the present work. Species sequenced for this study are highlighted in blue.

\begin{tabular}{|c|c|c|c|}
\hline & Species & Localities & Gen Bank code \\
\hline Outgroup & Prorhynchus stagnalis & & KC869866 \\
\hline \multirow[t]{37}{*}{ ACOTYLEA } & Callioplana marginata & Japan & LC100082 \\
\hline & Imogine zebra & Massachusetts & AF342800 \\
\hline & Imogine refertus & Brazil & KY263694 \\
\hline & Stylochus sp. & Peru & KY263743 \\
\hline & Paraplanocera oligoglena & Hawaii & KC869849 \\
\hline & Imogine ijimai & Japan & LC100079 \\
\hline & Leptostylochus gracilis & Japan & LC100078 \\
\hline & Latocestus plehni & Cape Verde Is. & MK299376 \\
\hline & & Canary Is. & MK299377 \\
\hline & Hoploplana villosa & Japan & LC100076 \\
\hline & Hoploplana californica & California & KC869850 \\
\hline & Hoploplana divae & Brazil & KY263692 \\
\hline & & Brazil & KY263693 \\
\hline & Paraplanocera $\mathrm{sp}$ & Greece & KY263699 \\
\hline & Planocera multitentaculata & Japan & LC100081 \\
\hline & Planocera pellucida & Canary Is. & MK299355 \\
\hline & & Cape Verde Is. & MK299356 \\
\hline & & Canary Is. & MK299363 \\
\hline & Amemiyaia pacifica & Japan & LC100077 \\
\hline & Adenoplana evelinae & Brazil & KY263647 \\
\hline & Phaenocelis medvedica & Brazil & KY263701 \\
\hline & & Brazil & KY263702 \\
\hline & Discocelis tigrina & Canary Is. & MK299370 \\
\hline & & Barcelona & AF022744 \\
\hline & Ilyella gigas & Japan & LC100080 \\
\hline & Leptoplana tremellaris & Spain & KY263695 \\
\hline & & Spain & KY263696 \\
\hline & Armatoplana leptalea & Brazil & KY263648 \\
\hline & & Brazil & KY263649 \\
\hline & Notoplana sp. & Brazil & KY263651 \\
\hline & & Brazil & KY263650 \\
\hline & Notoplana delicata & Japan & LC100088 \\
\hline & Koinostylochus elongatus & Japan & LC100083 \\
\hline & Pseudostylochus obscurus & Japan & LC100084 \\
\hline & Notoplana australis & Australia & AY157153 \\
\hline & Notocomplana humilis & Japan & LC100085 \\
\hline & Notocomplana sp. & Japan & LC100089 \\
\hline
\end{tabular}


Table 1 (continued).

\begin{tabular}{|c|c|c|}
\hline Species & Localities & GenBank code \\
\hline \multirow{3}{*}{ Cycloporus gabriellae } & Spain & KY263689 \\
\hline & Brazil & KY263656 \\
\hline & Brazil & KY263658 \\
\hline \multirow{2}{*}{$\begin{array}{l}\text { Eurylepta cornuta var. melobesiarum } \\
\text { Eurylepta } \text { sp. }\end{array}$} & Cape Verde & MK299350 \\
\hline & Martinica Is. & MK299372 \\
\hline Pseudoceros harrisi & Panama & EF514802 \\
\hline Pseudoceros astrorum & Brazil & KY263737 \\
\hline Pseudoceros atropurpureus & Japan & LC100098 \\
\hline Pseudoceros hancockanus & Japan & LC100100 \\
\hline \multirow[t]{4}{*}{ Pseudoceros velutinus } & Greece & KY263740 \\
\hline & Spain & KY263741 \\
\hline & Japan & LC100095 \\
\hline & Japan & LC100095 \\
\hline \multirow[t]{3}{*}{ Pseudoceros velutinus } & Cape Verde Is. & MK299360 \\
\hline & Cape Verde Is. & MK299380 \\
\hline & Canary Is. & MK299381 \\
\hline \multirow[t]{5}{*}{ Pseudoceros rawlinsonae } & Brazil & KY263731 \\
\hline & Brazil & KY263733 \\
\hline & Florida & GQ398102 \\
\hline & Bahamas & GQ398101 \\
\hline & Virgin Is. & EF514803 \\
\hline \multirow[t]{2}{*}{ Pseudoceros rawlinsonae var. galaxy } & Cape Verde Is. & MK299357 \\
\hline & Cape Verde Is. & MK299358 \\
\hline Pseudoceros nipponicus & Japan & LC100096 \\
\hline \multirow[t]{4}{*}{ Pseudoceros bicolor } & Brazil & KY263730 \\
\hline & Panama & GQ398096 \\
\hline & Florida & GQ398097 \\
\hline & Jamaica & GQ398100 \\
\hline Pseudoceros contrarius & Papua NG & KY263728 \\
\hline Yungia sp. & Florida & HQ659018 \\
\hline Yungia aurantiaca & Cádiz (Spain) & MK299386 \\
\hline Pseudobiceros nigromarginatus & Japan & LC100097 \\
\hline \multirow[t]{3}{*}{ Pseudobiceros pardalis } & Brazil & KY263723 \\
\hline & Panama & EF514807 \\
\hline & Panama & EF514808 \\
\hline Pseudobiceros wirtzi & Senegal & KY263725 \\
\hline Pseudobiceros bedfordi & Papua NG & KY263715 \\
\hline Maiazoon orsakii & Papua NG & KY263697 \\
\hline Phrikoceros mopsus & Brazil & KY263707 \\
\hline
\end{tabular}


Table 1 (continued).

\begin{tabular}{|c|c|c|c|}
\hline & Species & Localities & GenBank code \\
\hline & Notocomplana japonica & Japan & LC100087 \\
\hline & Notocomplana koreana & Japan & LC100086 \\
\hline \multirow[t]{37}{*}{ COTYLEA } & \multirow[t]{3}{*}{ Cestoplana rubrocinta } & Cyprus & MK299367 \\
\hline & & Cyprus & MK299368 \\
\hline & & Cyprus & MK299369 \\
\hline & Cestoplana salar & Brazil & KY263653 \\
\hline & \multirow[t]{3}{*}{ Cestoplana techa } & Brazil & KY263652 \\
\hline & & Brazil & KY263654 \\
\hline & & Brazil & KY263655 \\
\hline & \multirow[t]{2}{*}{ Pericelis sp. } & Cape Verde & MK299353 \\
\hline & & Cape Verde & MK299354 \\
\hline & Pericelis byerleyana & Martinica & MK299374 \\
\hline & \multirow[t]{4}{*}{ Pericelis cata } & Brazil & KY263700 \\
\hline & & Canary Is. & MK299351 \\
\hline & & Cape Verde & MK299352 \\
\hline & & Cape Verde & MK299373 \\
\hline & Boninia divae & Panama & KC869846 \\
\hline & Chromyella sp. & Panama & KC869848 \\
\hline & Theama sp. & Panama & KC869845 \\
\hline & \multirow[t]{5}{*}{ Anonymus ruber } & Canary Is. & MK299347 \\
\hline & & Cape Verde & MK299348 \\
\hline & & Cape Verde & MK299364 \\
\hline & & Cape Verde & MK299365 \\
\hline & & Cape Verde & MK299366 \\
\hline & \multirow[t]{2}{*}{ Enchiridium evelinae } & Brazil & KY263682 \\
\hline & & Brazil & KY263683 \\
\hline & \multirow[t]{2}{*}{ Enchiridium magec } & Canary Is. & MK299349 \\
\hline & & Canary Is. & MK299371 \\
\hline & Prosthiostomum grande & Japan & LC100090 \\
\hline & Prosthiostomum vulgare & Japan & LC100091 \\
\hline & \multirow[t]{2}{*}{ Cycloporus variegatus } & Brazil & KY263657 \\
\hline & & Spain & KY263659 \\
\hline & Cycloporus japonicus & Japan & LC100092 \\
\hline & \multirow[t]{2}{*}{ Maritigrella fuscopunctata } & Indo-Pacific & KU674837 \\
\hline & & Indo-Pacific & KU674838 \\
\hline & Prostheceraeus vittatus & Sweden & AJ315647 \\
\hline & \multirow[t]{2}{*}{ Maritigrella crozieri } & Florida & KY263686 \\
\hline & & Florida & KY263687 \\
\hline & Prostheceraeus roseus & Spain & KY263688 \\
\hline
\end{tabular}


Table 1 (continued).

\begin{tabular}{|c|c|c|}
\hline Species & Localities & Gen Bank code \\
\hline & Brazil & KY263709 \\
\hline & Brazil & KY263711 \\
\hline Monobiceros sp. & Cape Verde & MK299359 \\
\hline \multirow[t]{3}{*}{ Monobiceros langi } & Spain & KY263710 \\
\hline & Greece & KY263738 \\
\hline & Spain & KY263713 \\
\hline \multirow[t]{4}{*}{ Thysanozoon alagoensis } & Brazil, & KY263747 \\
\hline & Martinica Is. & MK299383 \\
\hline & Martinica Is. & MK299384 \\
\hline & Martinica Is. & MK299385 \\
\hline \multirow{6}{*}{$\begin{array}{l}\text { Pseudobiceros sp. } \\
\text { Pseudobiceros caribbensis }\end{array}$} & Santa Helena Is. & KY263724 \\
\hline & Florida & EF514805 \\
\hline & Jamaica & EF514806 \\
\hline & Martinica Is. & MK299378 \\
\hline & Martinica Is. & MK299379 \\
\hline & Cadiz (Spain) & MK299387 \\
\hline Pseudobiceros flavomarginatus & Japan & LC100099 \\
\hline \multirow[t]{2}{*}{ Pseudobiceros evelinae } & Brazil & KY263716 \\
\hline & Brazil & KY263717 \\
\hline Pseudobiceros splendidus & Florida & HQ659016 \\
\hline \multirow[t]{6}{*}{ Thysanozoon brocchii } & Brazil & KY263744 \\
\hline & Sicily & KY263745 \\
\hline & Australia & HQ659017 \\
\hline & Japan & LC100093 \\
\hline & Cape Verde & MK299361 \\
\hline & Canary Is. & MK299382 \\
\hline Thysanozoon japonicum & Japan & LC100094 \\
\hline Acanthozoon aranfaibo & Canary Is. & MK299362 \\
\hline \multirow[t]{2}{*}{ Thysanozoon raphaeli } & Panama & EF514809 \\
\hline & Belize & EF514810 \\
\hline
\end{tabular}

on the differences and similarities among these archipelagos and provides new evidence to reach key conclusions about their biogeography and fauna.

\section{Material and methods}

\section{Localities, sampling sites and material processed}

Azores (Fig. 1A)

The Azores is the northernmost archipelago $\left(37^{\circ} 44^{\prime} \mathrm{N}, 25^{\circ} 40^{\prime} \mathrm{W}\right)$ and includes nine islands: São Miguel, Pico, Terceira, São Jorge, Faial, Flores, Santa Maria, Graciosa and Corvo. 
Canary Islands (Fig. 1B)

The Canary archipelago $\left(28^{\circ} 06^{\prime} \mathrm{N}, 15^{\circ} 04^{\prime} \mathrm{W}\right)$ includes two island complexes or provinces: Santa Cruz de Tenerife with four large islands (El Hierro, La Gomera, La Palma and Tenerife) and Las Palmas with three main islands and some small ones (Fuerteventura, Gran Canaria, Lanzarote and Isla Lobos). The Chinijo archipelago is part of Las Palmas and includes five small islands (La Graciosa, Alegranza, Montaña Clara, Roque del Este and Roque del Oeste).

Madeira (Fig. 1B)

The Madeira archipelago $\left(32^{\circ} 45^{\prime} \mathrm{N}, 17^{\circ} 00^{\prime} \mathrm{W}\right)$ consists of five islands; two inhabited, Madeira and Porto Santo, and three small, uninhabited isles, the Desertas. Madeira enjoys a Mediterranean climate, like the Canary and Selvagens Islands, which is characterized by 3 months of dryness and high temperatures.

Cape Verde (Fig. 1C)

Cape Verde $\left(15^{\circ} 07^{\prime} \mathrm{N}, 23^{\circ} 37^{\prime} \mathrm{W}\right)$ is the southernmost archipelago of Macaronesia and is divided into two groups of islands, Ilhas de Barlovento and Ilhas de Sotavento. Cape Verde comprises ten large islands: Santo Antão, São Vicente, Santa Luzia, São Nicolau, Sal, Boa Vista (Barlovento Island) and Maio, Santiago, Fogo, and Brava (Sotavento Island) as well as five minor isles Raso, Branco, Grande, Cima and Carneiro.

\section{Southwestern Morocco (Fig. 1B)}

Although actually northern Morocco may not be part of Macaronesia, we include the species found in Agadir due to the similar ecological conditions and geographical proximity to the Canary Islands.

The study material from the Canary Islands, Cape Verde, Azores, Agadir and Ifni (Morocco) was collected by hand while scuba diving from rocks, the sea bottom, cave surfaces and macro-algae samples. Additional specimens were collected by taking rock and algae samples from the field to the laboratory and waiting for oxygen to be depleted, forcing animals to come out of hiding.

Exhaustive information about the external features was carefully recorded with notes, photographs and drawings. Information about pigmentation, color patterns, movement, size, and presence or absence of tentacles or eyes was gathered. Dorsal structures like papillae, warts or any type of epithelial or dermal formations were compiled.

Most of the photographs were taken on a black background with transmitted light using a Nikon D300 camera fitted with a Micro Nikon $60 \mathrm{~mm}$ lens, a Kenko extension tube and two wireless R1 speed lights.

\section{Histological processing}

For fixation, the individuals were previously anesthetized with seawater/magnesium chloride (7\%). A small piece of tissue was removed for molecular analysis and the whole individual was fixed in Bouin solution ( 0.8 gr of picric acid in $80 \mathrm{ml}, 20 \mathrm{ml}$ of formaldehyde and $2 \mathrm{ml}$ of acetic acid) for histological studies. Histological sagittal series from 6 to 12 micrometres thick were stained with AZAN trichrome. The histological preparations of the studied specimens were deposited in the collections of the Nacional Museum of Natural Sciences (MNCN), Madrid.

For the definitive identification of genus/species internal anatomic reconstructions, particularly of the reproduction apparatus, were made using a Zeiss Axio Scope A1 microscope.

\section{DNA extraction, amplification and sequencing}

Tissues for molecular studies were fixed in absolute ethanol. Total genomic DNA was extracted from each sample following the phenol-chloroform protocol (Chen et al. 2010). DNA concentration and 
purity of the extraction was measured using a NanoDrop Fluorospectrometer (Thermo Fisher Scientific). Sequences of the ribosomal gene $28 \mathrm{~S}$ of the investigated Polycladida species were studied. All PCRs were performed using Taq DNA polymerase of Mastermix (Invitrogen, Carlsbad, CA) following the manufacturer's protocol in a total volume of $25 \mu$ l.

Sequences of approximately $1100 \mathrm{bp}$ of the $28 \mathrm{~S}$ gene were amplified with degenerated primers designed de novo by the first two authors: forward primer (5'-AGCCCAGCACCGAATCCT3-') and reverse (5'-GCAAACCAAGTAGGGTGTCGC-3'). The PCR consisted in an initial denaturation step at $95^{\circ} \mathrm{C}$ ( $3 \mathrm{~min})$, followed a pre-cycle of 5 cycles of denaturation at $96^{\circ} \mathrm{C}(30 \mathrm{sec})$, annealing at $55^{\circ} \mathrm{C}(30 \mathrm{sec})$ and extension at $72^{\circ} \mathrm{C}(1 \mathrm{~min})$, followed by 40 cycles of denaturation at $95^{\circ} \mathrm{C}(30 \mathrm{sec})$, annealing at $59^{\circ} \mathrm{C}$ $(30 \mathrm{sec})$ and extension at $72^{\circ} \mathrm{C}(1 \mathrm{~min})$, with a final extension of $10 \mathrm{~min}$ at $72^{\circ} \mathrm{C}$.

Finally, the sequences obtained from forward and reverse primers were combined using the program Geneious R6 (ver. 6.1.5) (http://www.geneious.com; Kearse et al. 2012).

\section{Sequence alignment and phylogenetic analyses}

A comparative analysis with both newly obtained sequences and those obtained from the NCBI GenBank database was carried out. A total of 147 sequences were aligned and edited using Geneious R6 (ver. 6.1.5). Forty-one of them were new sequences (NCBI accession numbers in Table 1).

The newly obtained sequences of 1100 bps were adapted to the length of those gathered from GenBank. The alignment was generated using the program MAFFT ver. 7 (Katoh \& Standley 2013). Ambiguously aligned and variable regions were recognized and excluded using the program Gblocks ver. $0.91 \mathrm{~b}$ (Castresana 2000) with relaxed parameters (smaller final blocks, gap positions within the final blocks, and less strict flanking positions allowed). Thus, a matrix of $744 \mathrm{bp}$ was obtained.

Maximum likelihood (ML) was implemented through IQ-TREE (Trifinopoulos et al. 2016), using the evolutionary model BIC: TIM2+I+G4. The consensus tree of 1000 bootstrap pseudoreplicates was selected and edited with iTOL ver. 3.1.1 (Letunic \& Bork 2016).

Bayesian inference (BI) analyses were carried out using MrBayes ver. 3.2.2 (Ronquist et al. 2012) (-mset option). Two independent runs of 1000000 generations and four chains (one cold, three heated) were run. Trees were sampled every 1000 generations. Convergence of chains was diagnosed using a deviation of standard frequencies below 0.05 and of the 1001 sampled trees, 250 trees were discarded as burn-in. A majority-rule consensus tree was constructed from the remaining 751 trees to approximate posterior probabilities.

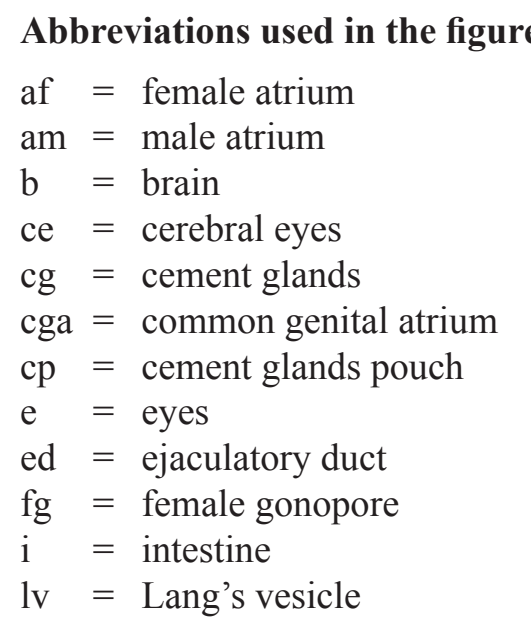




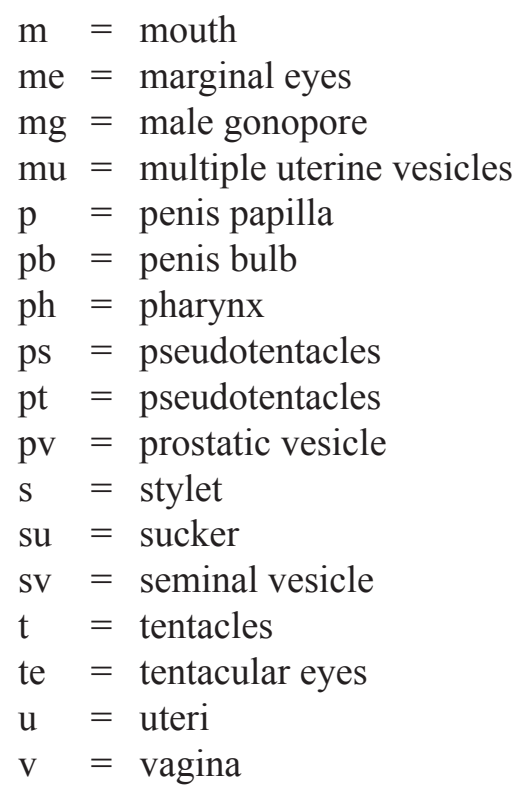

\section{Institutional acronyms for collections}

MNCN = Museo Nacional de Ciencias Naturales, Madrid, Spain

RCCN = Research Collection of Carolina Noreña, Museo Nacional de Ciencias Naturales, Madrid, Spain

\section{Results}

Table 2 lists the complete register of the Polycladida from the Macaronesian Archipelagos. New species and records are described as follows.

Azores (Fig. 1A). Currently, only six species are recorded for the Azores: Enchiridium cf. magec Cuadrado, Moro \& Noreña, 2017, Thysanozoon cf. brocchii (Risso, 1818), Prostheceraeus giesbrechtii Lang, 1884, Prostheceraeus cf. roseus Lang, 1884 and the new records Prostheceraeus moseleyi Lang, 1884 and Stylochus sp. (Table 2) (Wirtz 1994; Wirtz \& Debelius 2003).

Canary Islands (Fig. 1B). The species of the Canary Islands were listed and described recently in Cuadrado et al. (2017); therefore, only new records are described in this study: Discocelis tigrina (Blanchard, 1847) and Gnesioceros sargassicola (Mertens, 1833).

MadeIRA (Fig. 1B). Pseudoceros wirtzi (Bahia \& Schrödl, 2016), Pseudoceros cf. maximus Lang, 1884 and Prostheceraeus giesbrechtii (Wirtz \& Debelius 2003; Bahia \& Schröd1 2016) are the three polyclad species currently recorded for Madeira. The new record Planocera pellucida (Mertens, 1833) is recorded in this study.

CAPE Verde (Fig. 1C). 31 species are described for Cape Verde. The new records described in this study include Pericelis cata Marcus \& Marcus, 1968, Anonymus ruber Cuadrado, Moro \& Noreña, 2017, Eurylepta cornuta var. melobesiarum Lang, 1884, Cycloporus gabriellae Marcus, 1950, Pseudoceros velutinus (Blanchard, 1847), Pseudoceros mororum Cuadrado, Moro \& Noreña, 2017, Monobiceros langi Faubel, 1984 and Stylochus pillidium (Götte, 1881). Additionally, a new variety Pseudoceros rawlinsonae var. galaxy and six new species Marcusia alba sp. nov., Prostheceraeus crisostomus sp. nov., Stylochus salis sp. nov., Distylochus fundae sp. nov., Euplana claridade sp. nov. and Parviplana sodade sp. nov. are described. 


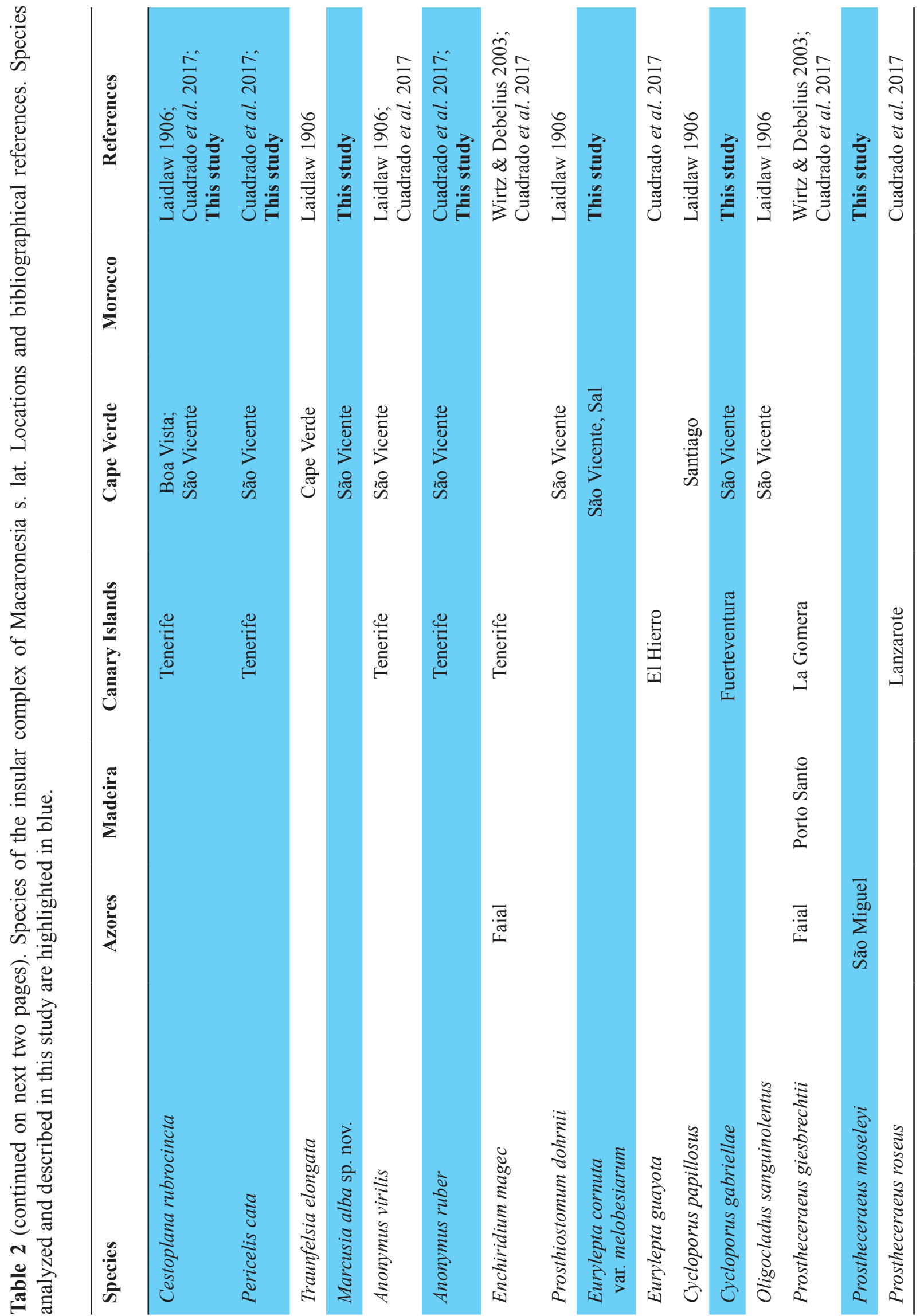




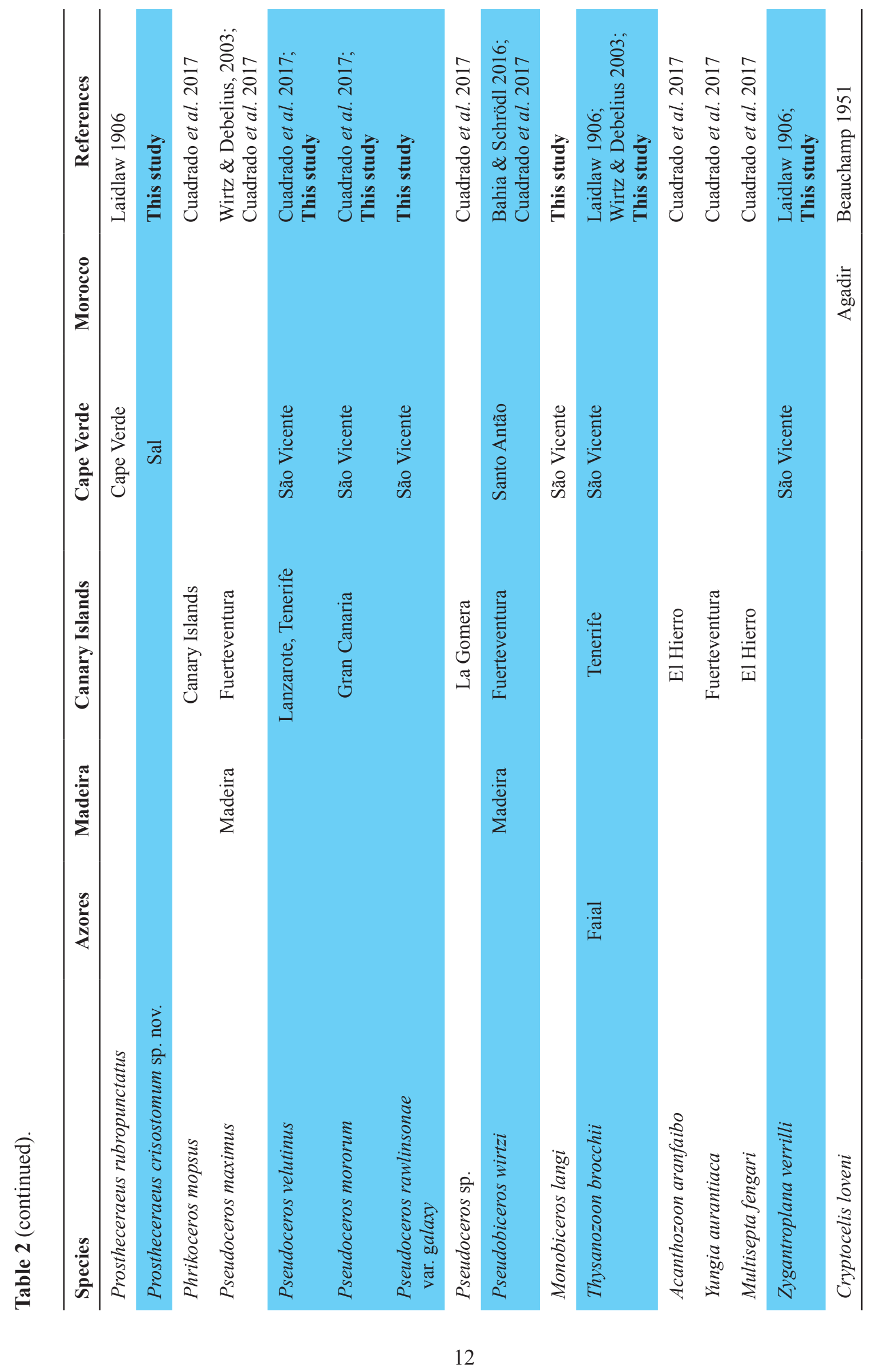




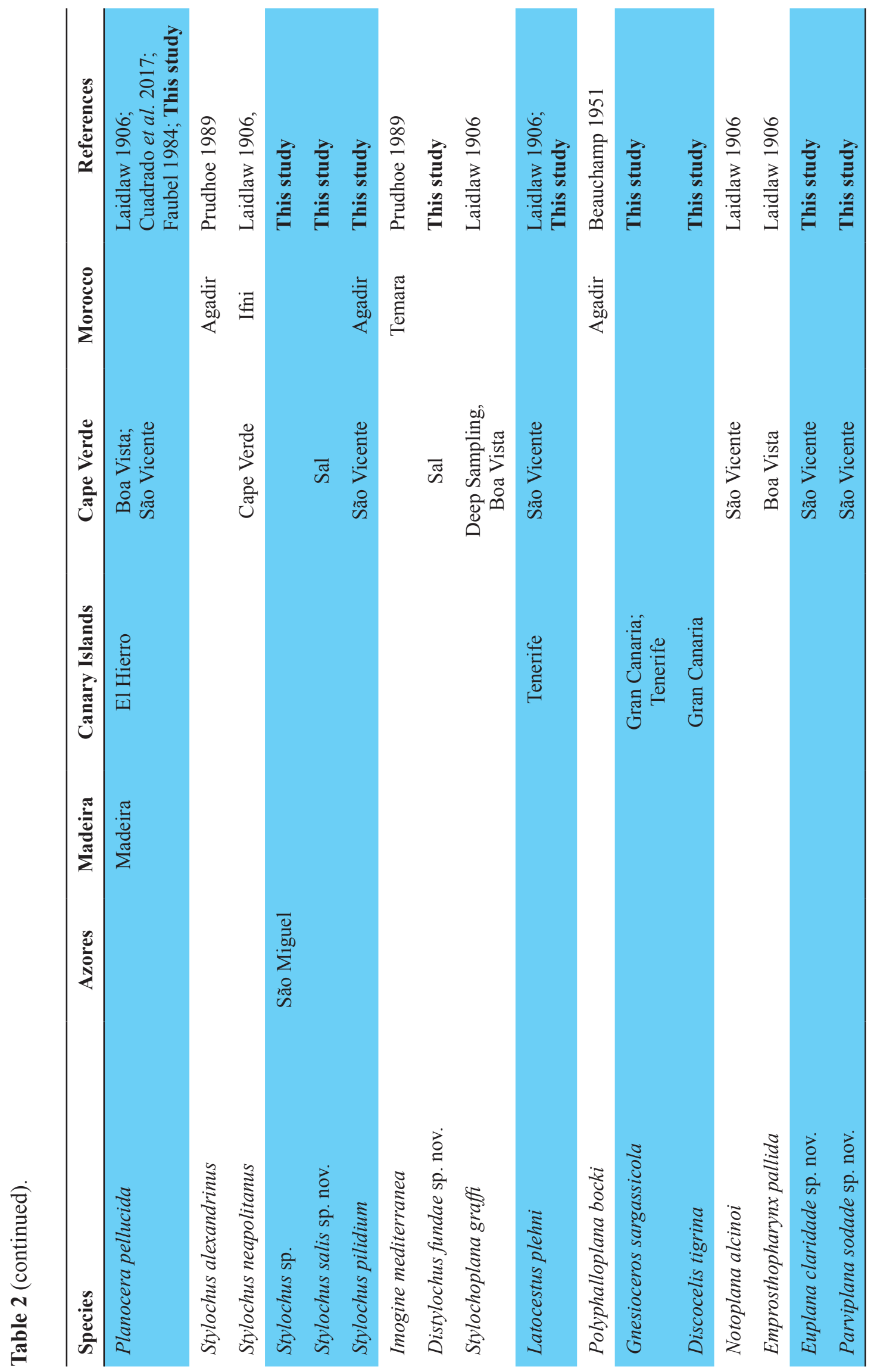


Southwestern Morocco (Fig. 1B). Four Polycladida species are known from the south coast near Agadir (Morocco), three species recorded by Beauchamp (1951): Polyphalloplana bocki Beauchamp, 1951, Stylochus alexandrinus Steinböck, 1937 and Cryptocelis loveni Bergendal, 1890, and Stylochus mediterraneus Galleni, 1976 by Prudhoe (1989). In the present study, two new records are described from Morocco, Stylochus neapolitanus (Delle Chiaje, 1841-1844) and Stylochus pilidium (Götte, 1881) (Table 2).

\section{New species and varieties}

Order Polycladida Lang, 1881

Suborder Cotylea Lang, 1884

Family Diposthidae Woodworth, 1898 sensu Litvaitis et al., 2019

Genus Marcusia Hyman, 1953

Marcusia alba sp. nov. urn:1sid:zoobank.org:act:DE4AF1C8-D784-4AB7-B536-A1E88524115B

Figs $1 \mathrm{C}, 2$

\section{Etymology}

The name of the new species, Marcusia alba, comes from the Latin 'albus' (white), and refers to the ivory white coloration this species shows.

\section{Material examined (3 specs)}

\section{Holotype}

CAPE VERDE • São Vicente Island, Mindelo; 1653'46.54" N, 2459'32.93" W (Fig. 1C V1); 6 May 2017; Leopoldo Moro leg.; MNCN 4.01/2620 to 2683 (64 slides). One sagittally sectioned specimen stained with AZAN.

\section{Additional material}

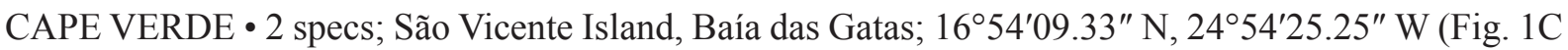
V2); 6 May 2017; Leopoldo Moro leg.; RCCN.

\section{Description}

Body. Shape oval. Length $2.6 \mathrm{~cm}$. Smooth dorsal surface. Background pigmentation ivory white, darker along the middle dorsal region of the body. Amber dots and thin brushstroke-like lines garnish the dorsal surface. A thin, dark stripe, sometimes interrupted, extends along the central dorsal line (Fig. 2A). Two delicate marginal folds, separate and pointed, could be interpreted as pseudotentacles. Tentacular eyes scarce and widely dispersed over the tentacles. Cerebral eyes anterior drop-shaped and crossed by the central midline. Marginal eyes only at the anterior part (Fig. 2B). Ruffled pharynx, in the middle of the body with a central oral pore. Ventral sucker at the posterior part of the body. Male and female genital pore lead in a common genital atrium (Fig. 2D-E) that opens in the posterior body region after the pharynx (Fig. 2C).

MALE REPRODUCTIVE SYSTEM. Male copulatory organ backwards oriented, with a muscular penis papilla, very muscular seminal vesicle (Fig. $2 \mathrm{C}, \mathrm{E}$ ) and without a prostatic vesicle, instead a simple glandular epithelium leads into the penis papilla (Fig. 2D-E). Seminal vesicle rounded, frontal oriented and with thick muscular walls, opening into the ejaculatory duct. Short ejaculatory duct opens into the penis papillae. The male atrium is small and thin, connected to the common atrium. 
Female Reproductive system (Fig. 2C, E). The vagina runs from the common genital atrium and continues dorsally into a narrowed duct that widens into a chamber, the cement pouch. The vagina continues dorsally, then curves posteriorly and ventrally and ends with the entry of the oviducts.

\section{Remarks}

Marcusia alba sp. nov. belongs to the genus Marcusia due to the presence of cerebral, frontal and marginal eyes, male copulatory organ enclosed in a muscular bulb, the absence of prostatic vesicle and the common male and female atrium genital, as well as the common gonopore.
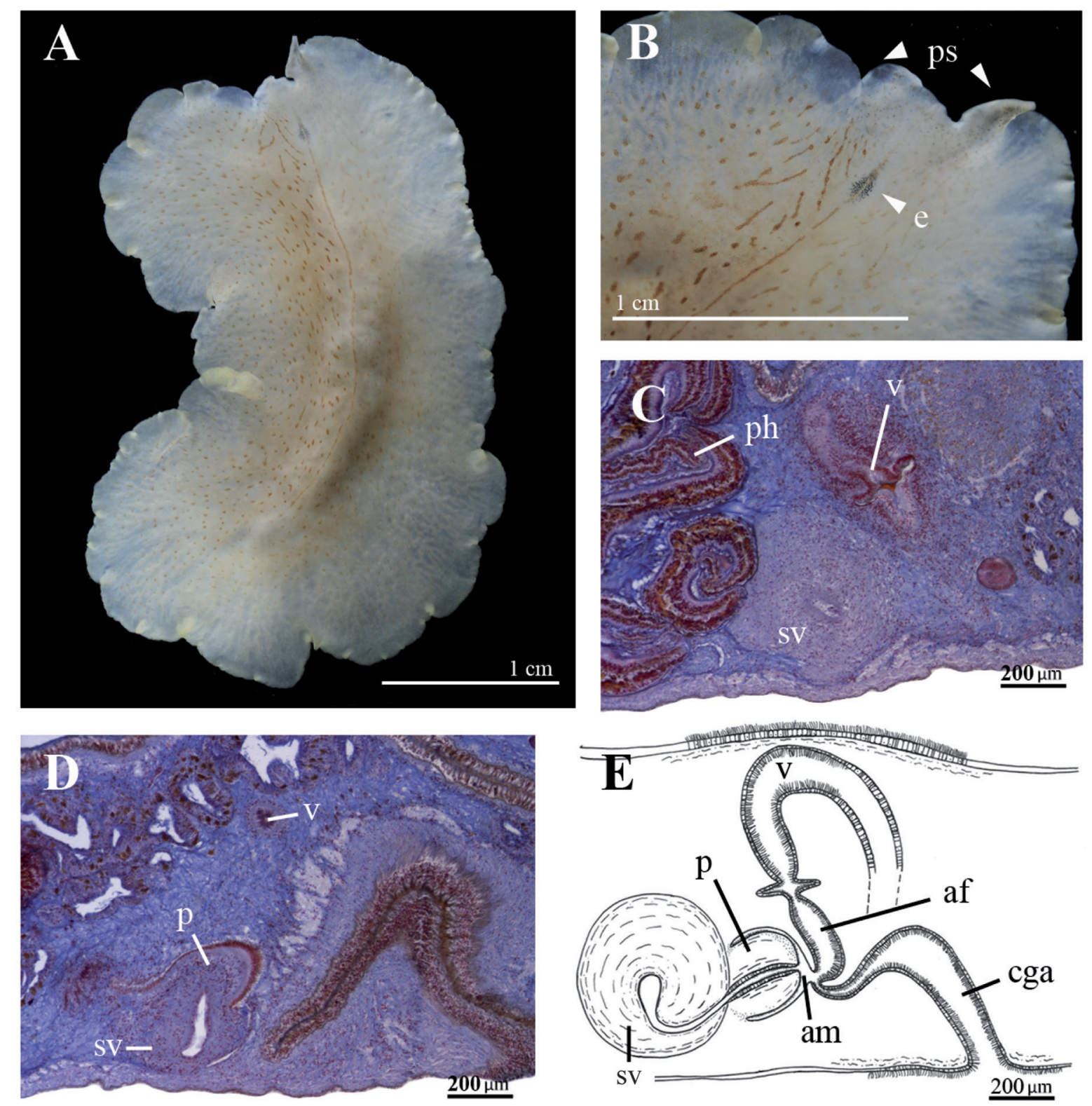

Fig. 2. Marcusia alba sp. nov. (MNCN 4.01/2620 to 2683). A. Whole live animal, dorsal view. B. Anterior region with cerebral eyes cluster and pseudotentacles (white arrows). C. Histological section of the male copulatory organ stained with AZAN. D. Histological section of the female copulatory organ stained with AZAN. E. Sagittal reconstruction of the reproduction system. Abbreviations: see Material and methods. 
The genus Marcusia contained only one species, Marcusia ernesti Hyman, 1953, known from the coast of the Gulf of California (Hyman 1953). Marcusia ernesti and M. alba sp. nov. can be easily distinguished by their coloration patterns. Marcusia ernesti is black or grey with darker splotches and dotted with white spots, only visible in preserved individuals after Hyman (1953), M. alba sp. nov. is ivory white with brownish dots and stripes. The penis papilla is spherical in $M$. alba and elongated in $M$. ernesti, with the male atrium being tube-like and longer in the Californian species.

Another difference lies in the eyes' presence and distribution. Marcusia ernesti presents marginal, frontal and cerebral eyes as well as two characteristic eye clusters with diagnostic value (Hyman 1953). Marcusia alba sp. nov., on the other hand, has cerebral, marginal and tentacular eyes, but not frontal eyes or eye clusters.

The differences listed are enough to consider M. ernesti and M. alba sp. nov. as two different species of the same genus. Furthermore, the molecular analyses show the genus Marcusia (represented in this case by Marcusia alba sp. nov.) as a genus closely related to Pericelis Laidlaw, 1902 within the family Anonymidae Lang, 1884, but as a clearly independent genus.

Family Euryleptidae Lang, 1884

Genus Prostheceraeus Schmarda, 1859

Prostheceraeus crisostomum sp. nov. urn:1sid:zoobank.org:act:EC7A7E2B-99FD-447D-A189-676144875AC2

Figs $1 \mathrm{C}, 3 \mathrm{~A}-\mathrm{D}$

\section{Etymology}

The name of the new species, Prostheceraeus crisostomum, is dedicated to the little cat, Crisostomo, roommate during the description of this species.

\section{Material examined}

\section{Holotype}

CAPE VERDE • Sal Island, Calheta Funda; 16³9'03.34" N, 2256'42,94" W (Fig. 1C V3); 8 Jul. 2018; Leopoldo Moro leg.; MNCN 4.01/2684 to 2698 (15 slides). One sagittally sectioned specimen stained with AZAN.

\section{Description}

BoDy. Shape elongated. Length $0.5 \mathrm{~cm}$. Smooth dorsal surface; background pigmentation ivory white, darker along the middle dorsal region of the body between the cerebral eyes and the posterior end of the body. In the posterior middle end it shows a large conspicuous black spot. Small black dots on the entire dorsal surface (Fig. 3E). Two marginal tentacles, separate. Tentacular eyes scarce and widely dispersed between the tentacles. Cerebral eyes arrow-shaped located by the central midline (Fig. 3F). Bell-shaped pharynx located in the first body half. Ventral sucker in the middle of the body. Male and female genital pores well separated and located after the pharynx (Fig. 3G-H).

Male ReProductive system. Male copulatory organ oriented forward. The muscular prominent penis papilla houses a conical, elongated stylet of pseudosclerotized nature. The rounded and well developed prostatic vesicle joins transversally with the sperm duct and lies over the penis papilla (Fig. $3 \mathrm{H}$ ). Muscular seminal vesicle oval, dorsally located and caudo-frontally oriented. The vasa deferentia join at the ventro-caudal region of the vesicle and the sperm duct open ventro-frontally. Seminal and prostatic vesicles open together into the proximal region of the developed penis papillae. The male atrium surrounded the penis papillae and opens near the posterior end of the pharynx. 
Female ReProductive system. Atrium elongated and highly ciliated, continues dorsally into the long but not ciliated vagina externa. The vagina externa narrows into a non-ciliated small cavity that continues in the vagina interna. It presents a widened epithelium and ends with the entry of the oviducts (Fig. 3H). Cement and shell glands lie around the female atrium, vagina externa and distal region of the vagina interna, but opens into the small cavity (pouch) between both vaginas.

\section{Remarks}

Prostheceraeus crisostomum sp. nov. belongs to the genus Prostheceraeus due to the presence of cerebral, frontal and marginal eyes, true anterior tentacles, bell-shaped pharynx, the male copulatory system with prostatic vesicle, penis armed whit stylet and the presence of multiple uterine vesicles.

The genus Prostheceraeus comprises 10 species, mainly characterized by coloration pattern, with colorful pigmentations and dorsal longitudinal lines of different widths, as in P. fuscolineatus Dixit, Raghunathan \& Chandra, 2017, P. roseus, P. pseudolimax Lang, 1884, P. giesbrechtii, P. vittatus (Montagu, 1815) and P. zebra (Hyman, 1955) or with fine, transversal lines as in P. crozieri (Hyman, 1939).
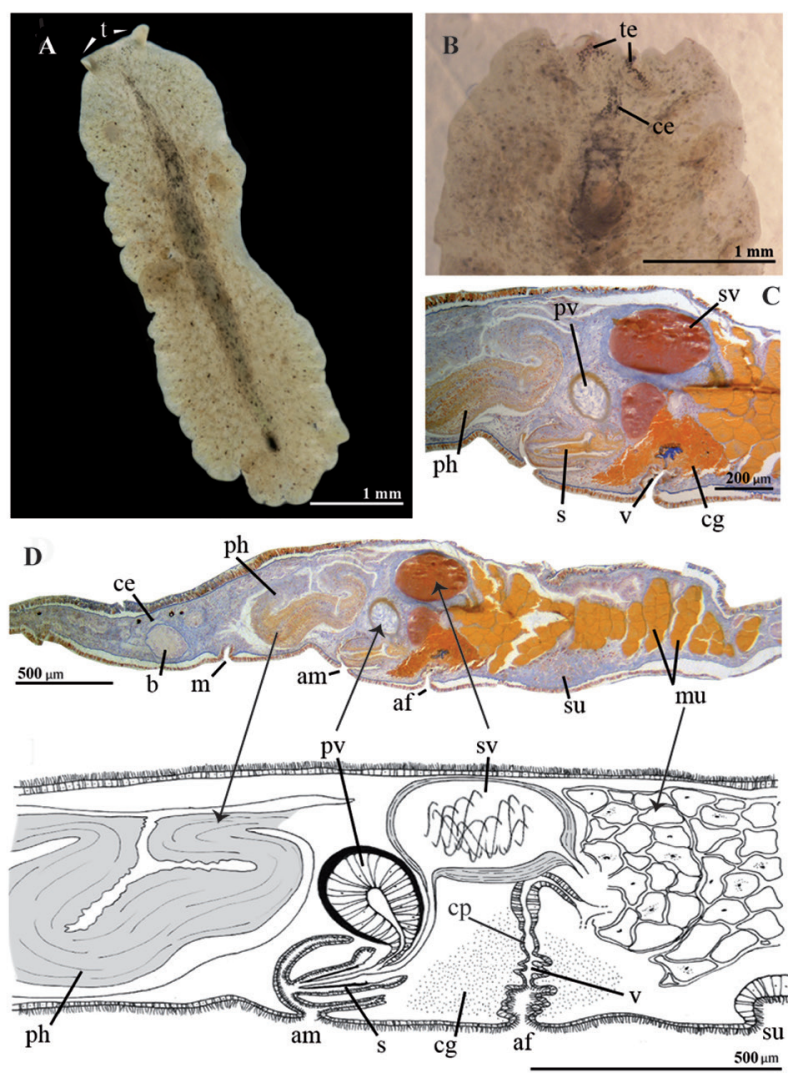
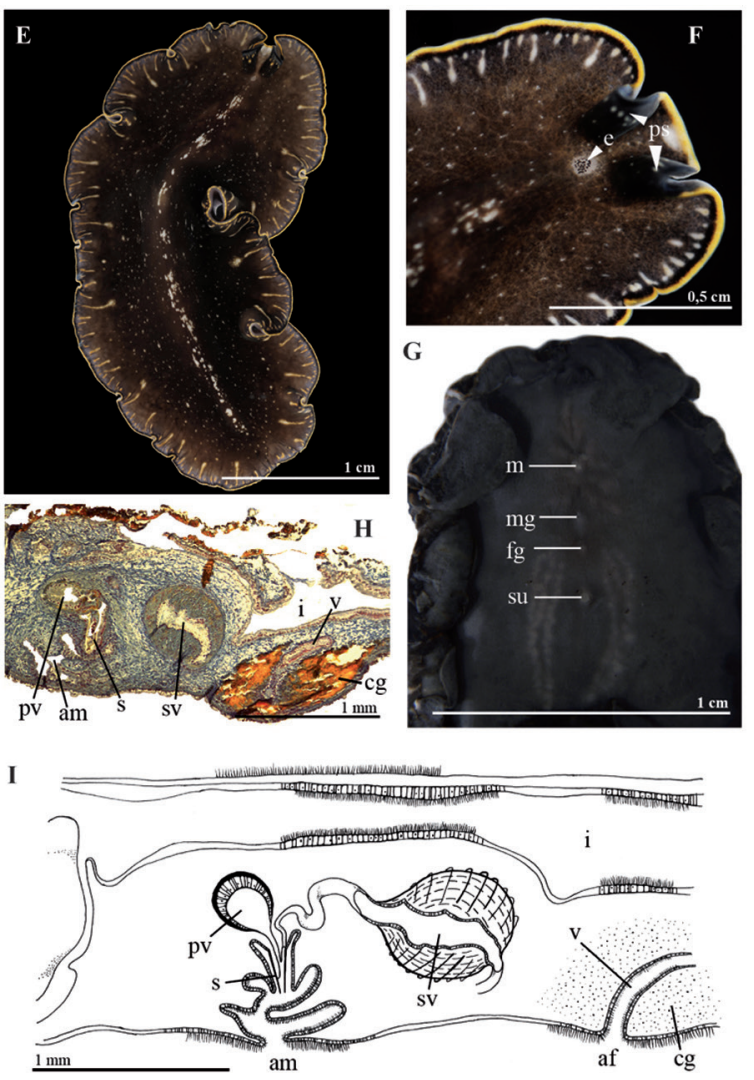

Fig. 3. A-D. Prostheceraeus crisostomum sp. nov. (MNCN 4.01/2684 to 2698). A. Whole live animal, dorsal view. B. Anterior region with cerebral eyes cluster and tentacles (black arrows). C. Histological section of the reproductive system stained with AZAN. D. Histological section of the whole animal stained with AZAN and sagittal reconstruction. - E-I. Pseudoceros rawlinsonae var. galaxy (MNCN $4.01 / 2729$ to 2798). E. Whole live animal, dorsal view. F. Anterior region with eyes cluster and tentacles (white arrows). G. Whole live animal, ventral view. H. Histological sagittal section of male and female copulatory organ. I. Sagittal reconstruction of the reproductive system. Abbreviations: see Material and methods. 
Three other species of Prostheceraeus show a color pattern free of lines or bands: P. albocinctus Lang, 1883, P. moseleyi and P. rubropunctatus Lang, 1884 . These three species, together with P. crisostomum sp. nov., have a dotted pattern, but the background colors are different in the four species: caramel brown background with white or whitish spots and white marginal line in P. albocinctus, blue-gray or cream background with black dots and yellow marginal band in P. moseleyi and finally P. rubropunctatus with a pink to reddish background color, white dots and without marginal band. The base coloration of $P$. crisostomum is similar to $P$. albocinctus, but much clearer and almost ivory; the dorsal points are black like in $P$. moseleyi and lacks a marginal line or band similar to P. rubropunctatus. All these differences delimit $P$. crisostomum sp. nov. as a new species of the genus Prostheceraeus.

Family Pseudocerotidae Lang, 1884

Genus Pseudoceros Lang, 1884

Pseudoceros rawlinsonae var. galaxy var. nov.

Figs $1 \mathrm{C}, 3 \mathrm{E}-\mathrm{I}$

\section{Etymology}

The name 'galaxy' comes from the pattern of the small white spots on the dorsal surface, which resemble a star galaxy.

\section{Material examined (2 specs)}

\section{Holotype}

CAPE VERDE • São Vicente Island, Baía das Gatas; 1654'09.33" N, 245'ㄹ․25" W (Fig. 1C V2); 5 May 2017; Leopoldo Moro leg.; MNCN 4.01/2729 to 2798 (70 slides). One sagittally sectioned specimen stained with AZAN.

\section{Additional material}

CAPE VERDE • 1 spec.; same collection data as for holotype; RCCN.

\section{Description}

Body. Shape oval. Length $2.3 \mathrm{~cm}$. Smooth dorsal surface. Background color dark to velvety brown with white dots and spots that draw a longitudinal line along the body axis. One thin bright yellow external line and another internal and black line surround the entire body margin. The yellow one is interrupted at the pseudotentacles level (Fig. 3E-F). Marginal body edges lined with transversal whitish elongated drops (Fig. 3F). Ventral coloration dark grey to black. Ventral sucker in the middle of the body (Fig. 3G). Pseudotentacles constitute two simple folds that present each of them a small cluster of tentacular eyes in their margin. Round cluster of cerebral eyes present and surrounded by a spot of white pigment. Pharynx ruffled, butterfly-shaped and located at the anterior third of the body. Oral pore, female and male gonopore close to each other and located at the anterior end (Fig. 3G). Male and female genital pores located after the pharynx in the anterior half of the body (Fig. 3H-I).

MaLe ReProductive system. Male genital pore between the posterior lobes of the ruffled pharynx. Male copulatory organ dorso-ventrally orientated consists in a prostatic vesicle and a very muscular seminal vesicle, as well as a penis papilla armed with a stylet (Fig. 3H-I). Vasa deferentia open separately into the seminal vesicle. Seminal vesicle rounded, frontally oriented and lined with a thick muscular wall. Prostatic vesicle rounded, muscular and smaller than the seminal vesicle. Sperm duct muscular and long, extends frontally to join the prostatic duct inside the proximal end of the conical stylet. The short ejaculatory duct appears surrounded by the stylet cone and the penis sheath. The male atrium is wide and tetra-folding (fork-like) as characteristic of the genus (Fig. 3I). 
Female Reproductive system. With a short muscular vagina, backwards oriented and surrounded by cement glands.

\section{Remarks}

The genus Pseudoceros comprises approximately 89 species with similar copulatory organs, but bright and unique coloration patterns. However, within these patterns some taxa share evident similarities. Pseudoceros rawlinsonae var. galaxy shares with P. bicolor Verril, 1902, P. mororum and P. rawlinsonae Bolaños, Quiroga \& Litvaitis, 2007 the brown background and one whitish, broad marginal band, but in P. bicolor the marginal band is wide with inner waves (Litvaitis et al. 2010: fig. 4a-i); P. rawlinsonae shows, in addition to the wide band, a thin orange line (Litvaitis et al. 2010: fig. 4j-p); in P. mororum the whitish band is interrupted and drop-shaped and additionally, two orange marginal stripes border the entire body (Cuadrado et al. 2017: fig. 6a-b); finally, the Cape Verdean species shows, together with the drop-shaped white band, two black and orange thin lines (Fig. 3E-F).

Although the four previously mentioned species can be clearly differentiated due to their coloration, this is not the case in the molecular analysis (Fig. 8). In both the Bayesian and Maximum Likelihood analyses, individuals from Cape Verde appear closely related to $P$. rawlinsonae, so much so that the separation of both populations (the Cape Verdean population and the Caribbean population) is only possible at the level of variety, not of species. Therefore, we determined the individuals from Cape Verde as a variety within the species $P$. rawlinsonae.

Nonetheless, we want to emphasize that the decision to maintain this population (organisms) as a 'variety' of the species P. rawlinsonae is the sole and exclusive responsibility of the authors. We are aware that 'variety' is not a taxonomic category (according to ICZN) and that therefore it will remain a non-existent species until molecular analyses allow us to consider it as such.

$$
\begin{gathered}
\text { Suborder Acotylea Lang, } 1884 \\
\text { Superfamily Leptoplanoidea Faubel, } 1984 \\
\text { Family Leptoplanidae Stimpson, } 1857 \\
\text { Genus Parviplana Hyman, } 1953 \\
\text { Parviplana sodade sp. nov. } \\
\text { urn:1sid:zoobank.org:act:10171C70-7431-41EF-B39D-AC3982D24143 }
\end{gathered}
$$

Figs $1 \mathrm{C}, 4 \mathrm{~A}-\mathrm{C}$

\section{Etymology}

The name of the new species, Parviplana sodade, comes from 'sodade' the Cape Verdean expression for saudade and regional song with rhythms of 'coladeira'.

\section{Material examined}

\section{Holotype}

CAPE VERDE • São Vicente Island, Mindelo; 1653'46.54" N, 2459'32.93" W (Fig. 1C V1); 24 Nov. 2017; Leopoldo Moro leg.; MNCN 4.01/2699 to 2708 (10 slides). One sagittally sectioned specimen stained with AZAN.

\section{Description}

Body. Shape oval elongated. Length $0.8 \mathrm{~cm}$. Smooth dorsal surface. Background pigmentation light white, transparent where the intestinal braches can be appreciated (Fig. 4A-B). Four clusters of cerebral eyes, two anterior with few eyes and more elongated than the posterior two. In sum around 50 cerebral eyes (Fig. 4B). Ruffled pharynx. Male and female genital pores located in the posterior half of the body. 
Male reproductive system. Directed backwards and with a dorso-ventrally oriented penis papilla. With elongated prostatic vesicle, tall granular lining included in the muscular penis bulb (Fig. 4C). The vasa deferentia enter the seminal vesicle separately. Seminal vesicle rounded, below the penis bulb and connected with a sort seminal duct to the prostatic vesicle (Fig. 4C). The male atrium is small and thin, with an internal fold that surrounds the distal part of the penis bulb like a penis sheath (Fig. 4C).

Female reproductive system. With a vagina bulbosa (Fig. 4C) and backwards oriented. Cement and shell glands open in a pouch located within the vaginal complex. Lang's vesicle present.

\section{Remarks}

Parviplana sodade sp. nov belongs to the genus Parviplana due to the absence of tentacles, presence of seminal vesicle, and prostatic vesicle with a tall granular lining with prostatic functions. Female apparatus with vagina bulbosa and Lang's vesicle.

Parviplana comprises 3 species, P. hymani Faubel, 1983, P. jeronimoi Pérez-García, Noreña \& Cervera, 2018 and P. lynca (Du Bois-Reymond Marcus, 1958). Parviplana lynca can be easy and clearly distinguished from the other two species by the presence of nuchal tentacles, exclusive of this species.

Parviplana hymani can be distinguished from P. sodade sp. nov., by the vas deferens which opens together into the seminal vesicle, and the prostate vesicle not included into de penis bulb.

Parviplana sodade sp. nov. possesses more similarities with P. jeronimoi. Both species share the penis sheath and more than 25 cerebral eyes, but clear differences separate them. Parviplana jeronimoi has a fleshy appearance and amber pigmentation. The size is also noticeable different, $P$. jeronimoi can reach lengths of $20 \mathrm{~mm}$, while $P$. sodade in full mature state does not reach $8 \mathrm{~mm}$. Parviplana jeronimoi also presents vasa deferentia joined in a single vas deferens, a small female atrium and a corrugated surface between the two genital pores, characteristics not present in P. sodade.

Family Euplanidae Marcus \& Marcus, 1966

Genus Euplana Girard, 1893

Euplana claridade sp. nov. urn:1sid:zoobank.org:act:C7E211FD-32AF-4FA4-A3EB-ACA1737DF2EE

Figs $1 \mathrm{C}, 4 \mathrm{D}-\mathrm{H}$

\section{Etymology}

The name of the new species, Euplana claridade, comes from "Claridade", a journal of literary review that revolutionized Cape Verdean culture during the first half of the twentieth century.

\section{Material examined}

\section{Holotype}

CAPE VERDE • São Vicente Island, Mindelo; 1653'46.54" N, 2459'32.93" W (Fig. 1C V1); 23 Nov. 2017; Leopoldo Moro leg.; MNCN 4.01/2709 to 2718 (10 slides). One sagittally sectioned specimen stained with AZAN.

\section{Description}

Body. Shape oval. Length $1.1 \mathrm{~cm}$. Smooth dorsal surface. Background pigmentation ivory white, denser along the middle dorsal region of the body and in the intestinal braches (Fig. 4D). Two clusters of 16 cerebral eyes each (Fig. 4E). Ruffled pharynx. Male and female genital pores located in the second half of the body close behind the posterior end of the pharynx. 
Male ReProductive system. Male copulatory organ backwards oriented, englobed in a muscular bulb with a small penis papilla. Vas deferens opens proximally into the ejaculatory duct (Fig. 4F-H). Without prostatic or seminal vesicle. Male atrium deep and thickened in the point of union with the penis (Fig. 4F-H).

Female RePRoductive system. Rounded female atrium (Fig. 4F-H). Vagina backwards oriented, surrounded by muscular fibres. Without Lang's vesicle.

\section{Remarks}

Euplana claridade sp. nov. belongs to the genus Euplana due to the absence of tentacles, prostatic vesicle and Lang's vesicle, and presence of a true seminal vesicle and elongated coiling ejaculatory duct.

The genus Euplana encompasses 3 species, E. carolinensis Hyman, 1940, E. gracilis Girard, 1853 and E. hymanae Marcus, 1947. The three species can be differentiated through the eyes number and disposition of them. E. gracilis and E. carolinensis present four cluster of eyes, two cerebral and two tentacular; E. hymanae and E. claridade sp. nov. only show two groups of cerebral eyes.
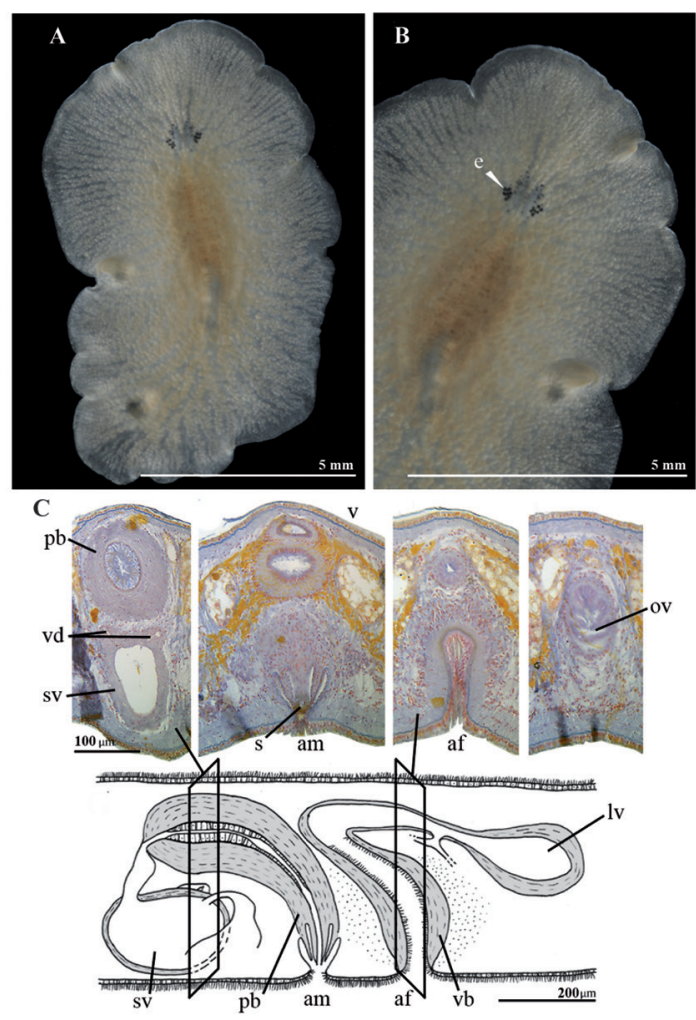
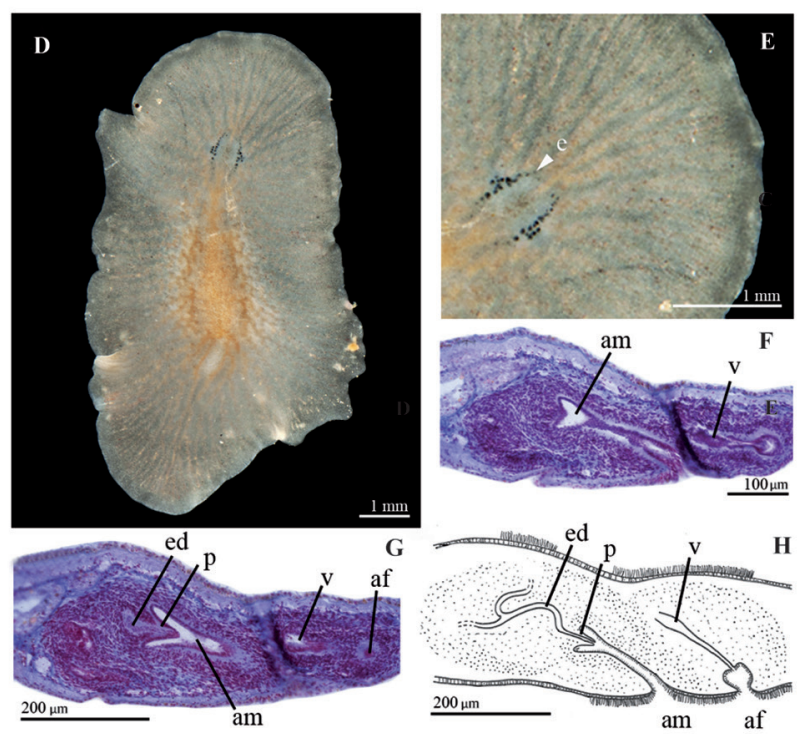

Fig. 4. A-C. Parviplana sodade sp. nov. (MNCN 4.01/2699 to 2708). A. Whole live animal, dorsal view. B. Anterior region with eyes cluster and tentacles (white arrows). C. Histological cross sections of male and female copulatory organ stained with AZAN and sagittal reconstruction of the reproductive system. - D-H. Euplana claridade sp. nov. (MNCN 4.01/2709 to 2718). D. Whole live animal, dorsal view. E. Anterior region with cerebral eyes cluster and tentacles (white arrows). F. Histological section of female copulatory organ stained with AZAN. G. Histological section of male copulatory organ stained with AZAN. H. Sagittal reconstruction of reproductive system. Abbreviations: see Material and methods. 
Within the reproductive system another differences can have founded, E. gracilis and E. hymanae present a small, short male atrium and a backwards oriented vagina externa, while E. carolinensis and E. claridade sp. nov. share a long tubular male atriumand a forward directed vagina externa.

Both species differ mainly in the male copulatory organ. The ejaculatory duct in E. carolinensis is wide and straight and by E. claridade sp. nov. is narrow and sinuous. Furthermore, the penis papilla is very short in E. carolinensis, while in E. claridade sp. nov. it is longer in comparison. On the other hand, the seminal vesicle is practically non-existent in $E$. claridade sp. nov., represented by the confluence of the two vasa deferentia, while in E. carolinensis it is a well-developed seminal vesicle, surrounded by circular muscles and in which the vas deferens empties proximally.

Superfamily Stylochoidea Poche, 1926

Family Stylochidae Stimpson, 1857

Genus Stylochus Ehrenberg, 1831

Stylochus salis sp. nov.

urn:1sid:zoobank.org:act:8A640FC8-D74C-4617-9766-F0FB9806BD4B

Figs $1 \mathrm{C}, 5 \mathrm{~A}-\mathrm{D}$

\section{Etymology}

The name of the new species, Stylochus salis refers to the type locality, Sal, a Cape Verdean Island.

Material examined (2 specs)

Holotype

CAPE VERDE • Sal Island, Calheta Funda; 16³9'03.34" N, 2256'42.94" W (Fig. 1C V3); 12 Nov. 2018; Leopoldo Moro leg.; MNCN 4.01/2719 to 2723 (5 slides). One sagittal sectioned specimen stained with AZAN.

\section{Additional material}

CAPE VERDE • 1 spec.; Sao Vicente Island, Mindelo (Fig. 1C V1); 1653'46.54" N, 2459'32.93" W; 6 May 2017; Leopoldo Moro leg.; RCCN.

\section{Description}

BoDy. Shape elongated. Length $0.4 \mathrm{~cm}$. Smooth dorsal surface. Background pigmentation cream white with an orange internal outline, sometimes interrupted, along the body margin and bordered by a white/ creamy outer band (Fig. 5A). Few cerebral and marginal eyes, scattered between the tentacles and anterior end (Fig. 5C). Two small nuchal tentacles with abundant basal eyes (Fig. 5B). Ruffled pharynx in the middle of the body and the oral pore in the end of the pharynx pouch and close to the gonopores. Male and female gonopores located close together in the posterior end of the body.

MALE RePRODUCtive system. Male copulatory organ backwards oriented and provided with an inconspicuous unarmed penis papilla. Prostatic vesicle muscular with granular lining (polyglandulartype after Bulnes et al. 2005) (Fig. 5D). Seminal vesicle elongated, empties at the distal end of the prostatic vesicle. The short penis papilla and ejaculatory duct emerge in a small male atrium (Fig. 5D).

Female ReProductive system. Shows the characteristic configuration of the genus. A tubiform canal with s-shaped ending in a small widening. 


\section{Remarks}

Stylochus salis sp. nov. belongs to the genus Stylochus due to the presence of gonopores separate and arranged in the second body half. With large and much ruffled pharynx. Tentacular, cerebral, marginal, and often frontal eye-spots present. Male copulatory apparatus with seminal vesicle and papillate penis. Lang's vesicle lacking (after Faubel 1983).

Stylochus salis sp. nov. clearly differs from other known species of Stylochus Ehrenberg, 1831 by its peculiar cream pigmentation bordered with the internal orange outline and the white/creamy outer band. The color of the eastern Atlantic known species (S. alexandrinus, S. castaneus Palombi, 1939, S. neapolitanus, S. plessissii Lang, 1884, and S. suesensis Ehrenberg, 1831) varies between brown, light brown, reddish or beige and spotted as in S. neapolitanus. None of them present a continuous (or discontinuous) marginal line.

The most conspicuous anatomical feature is the location of the oral pore, very close to the gonopore, clearly different from the central position of the oral pore in this genus. The peculiar location of the oral and genital pores distinguishes $S$. salis sp. nov. from the remaining species. Such a close location of the pores could only be found in the genus Latocestus Plehn, 1896 (Latocestidae, Stylochoidea).
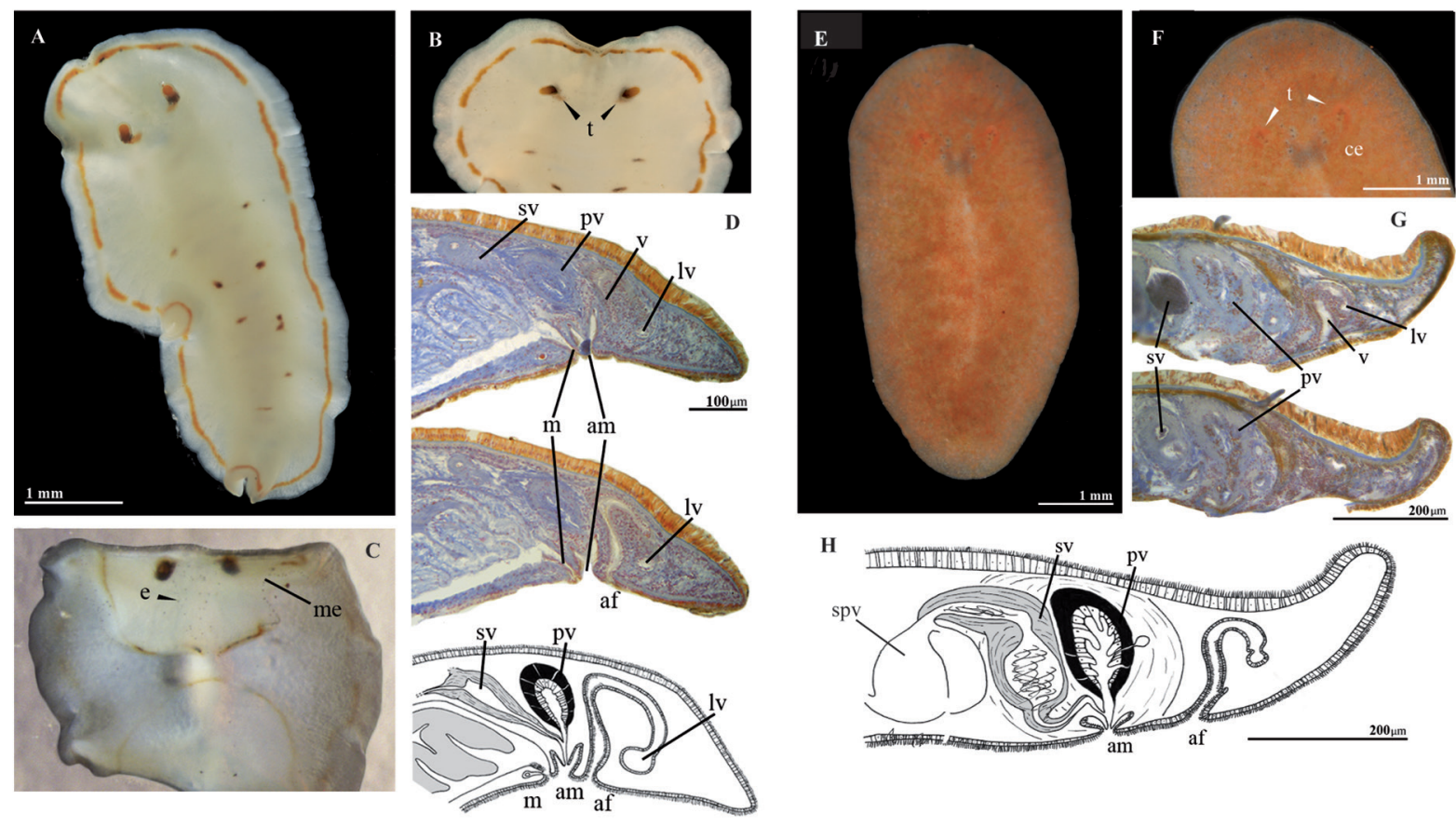

Fig. 5. A-D. Stylochus salis sp. nov. (MNCN 4.01/2719 to 2723). A. Whole live animal, dorsal view. B. Anterior region with eyes cluster and tentacles (black arrows). C Whole live animal ventral view. D. Histological sagittal sections of the reproductive system and sagittal reconstruction. $-\mathbf{E}-\mathbf{H}$. Distylochus fundae sp. nov. (MNCN 4.01/2724 to 2725). E. Whole live animal, dorsal view. F. Anterior region with cerebral eyes and tentacles (white arrows). G. Histological sagittal section of the reproductive system. H. Sagittal reconstruction of reproductive system. Abbreviations: see Material and methods. 
Genus Distylochus Faubel, 1983

Distylochus fundae sp. nov. urn:lsid:zoobank.org:act:27AE0619-D25F-48A0-8345-31D38765F732

Figs $1 \mathrm{C}, 5 \mathrm{E}-\mathrm{H}$

\section{Etymology}

The name of the new species, Distylochus fundae sp. nov. refers to the type locality Calheta Funda in the Island of Sal.

\section{Material examined}

\section{Holotype}

CAPE VERDE • Sal Island, Calheta Funda; 16³9'03.34" N, 2256'42.94" W (Fig. 1C V3); 14 Nov. 2018; Leopoldo Moro leg.; MNCN 4.01/2724 to 2725 (5 slides). One sagittally sectioned specimen stained with AZAN.

\section{Description}

Body. Shape elongated. Length $0.4 \mathrm{~cm}$. Smooth dorsal surface. Background pigmentation orange-garnet (Fig. 5E). Cerebral and tentacular eyes, scattered between the small tentacles (Fig. 5F). Ruffled pharynx, well developed, extending along $2 / 3$ of the body. Male and female genital pores located in the posterior half of the body, together, but clearly separated.

Male Reproductive system. Male copulatory system backwards oriented, with a small penis papilla. Prostatic vesicle surrounded by muscular layers and lined with fingered granular lining, most probably polyglandular (Fig. 5G-H). Seminal vesicle divided into two sections. A muscular and elongated proximal section, and a more rounded distal section provided with a thin wall. Both regions separated by muscle narrowing (Fig. 5H). The distal section leads to the seminal duct that opens into the prostatic duct and forms a short ejaculatory duct. The two vasa deferentia dilated to form spermatic vesicles, open into the proximal section. Male atrium small, englobing a short penis papilla (Fig. 4H).

Female ReProductive system. Apparatus simple and backwards oriented. Comprises an elongated tube without clear differentiation between external and internal vagina and ends in a small widening, without Lang's vesicle.

\section{Remarks}

The new species belongs to the genus Distylochus due to the presence of few scattered marginal, tentacular and cerebral eyes. Gonopores together and are located near the posterior end. Male apparatus with a short papilla and unarmed. Seminal vesicle configured in two regions, following the "doublevesicle-system" after Faubel (1983) and female apparatus simple, without Lang's vesicle.

There are currently only three known species for the genus Distylochus: D. pusillus (Bock, 1913) recorded for Hong Kong, D. martae (Marcus, 1947) in Brazil and D. isifer (Du Bois-Reymond, 1955) also from Brazil. These species were described on fixed specimens, therefore the colors are unknown, but apparently and after the original descriptions, they have pale pigmentation that contrast sharply with the orange-vermilion colors of the new species.

The most conspicuous difference of the new species is the disposition of female and male gonopore. In Distylochus fundae sp. nov. the gonopores are clearly separated, while in the Brazilian species are common and in the Chinese species are very close together. 


\section{New records}

Following the known species that are captured in the study area. All of them have been studied through photographs and histological sections, currently in RCCN.

Suborder Cotylea Lang, 1884

Family Euryleptidae Lang, 1884

Genus Eurylepta Ehrenberg, 1831

Eurylepta cornuta var. melobesiarum (Schmidtlein, 1880)

Figs 1C, 6

\section{Material examined}

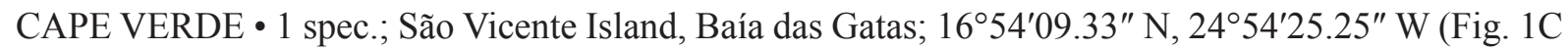
V2); May 2017; Leopoldo Moro leg.; RCCN.

\section{Distribution}

Ireland (Thompson 1845); Norway (Müller 1776); northwest France (Keferstein 1868); United Kingdom (Gamble 1893).

\section{New record}

São Vicente Island, Cape Verde.

\section{Description}

Body shape oval. Length $0.5 \mathrm{~cm}$. Smooth dorsal surface; background color red-orange, with white dots scattered over the dorsal surface (Fig. 6A-C). Ventral sucker in the posterior half of the body (Fig. 6F). Small tentacles. Few tentacular eyes distributed frontally and at the base of the tentacles. Cerebral eyes fused in a single elongated oval cluster (Fig. 6B). Ruffled pharynx located at the anterior third of the body. Oral pore posterior to the cerebral ganglion.

The reproductive system coincides with the original description, presenting the characteristic fold in front of the female genital pore mentioned by Lang (1884) for some specimens (Fig. 6D-F).

Genus Cycloporus Lang, 1884

Cycloporus gabriellae Marcus, 1950

Figs 1C, 7B

\section{Material examined}

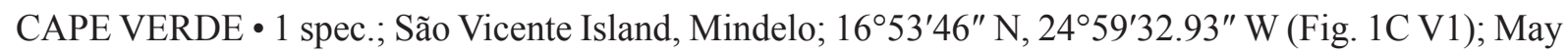
2017; Leopoldo Moro leg.; RCCN.

\section{Distribution}

São Sebastião Isle, Brazil (Marcus 1950); São Paulo, Brazil (Marcus 1952); Antigua and Barbuda; Curação, Netherlands Antilles; Isla de Aves, Venezuela (Marcus \& Marcus 1968).

\section{New record}

Mindelo, São Vicente Island, Cape Verde. 

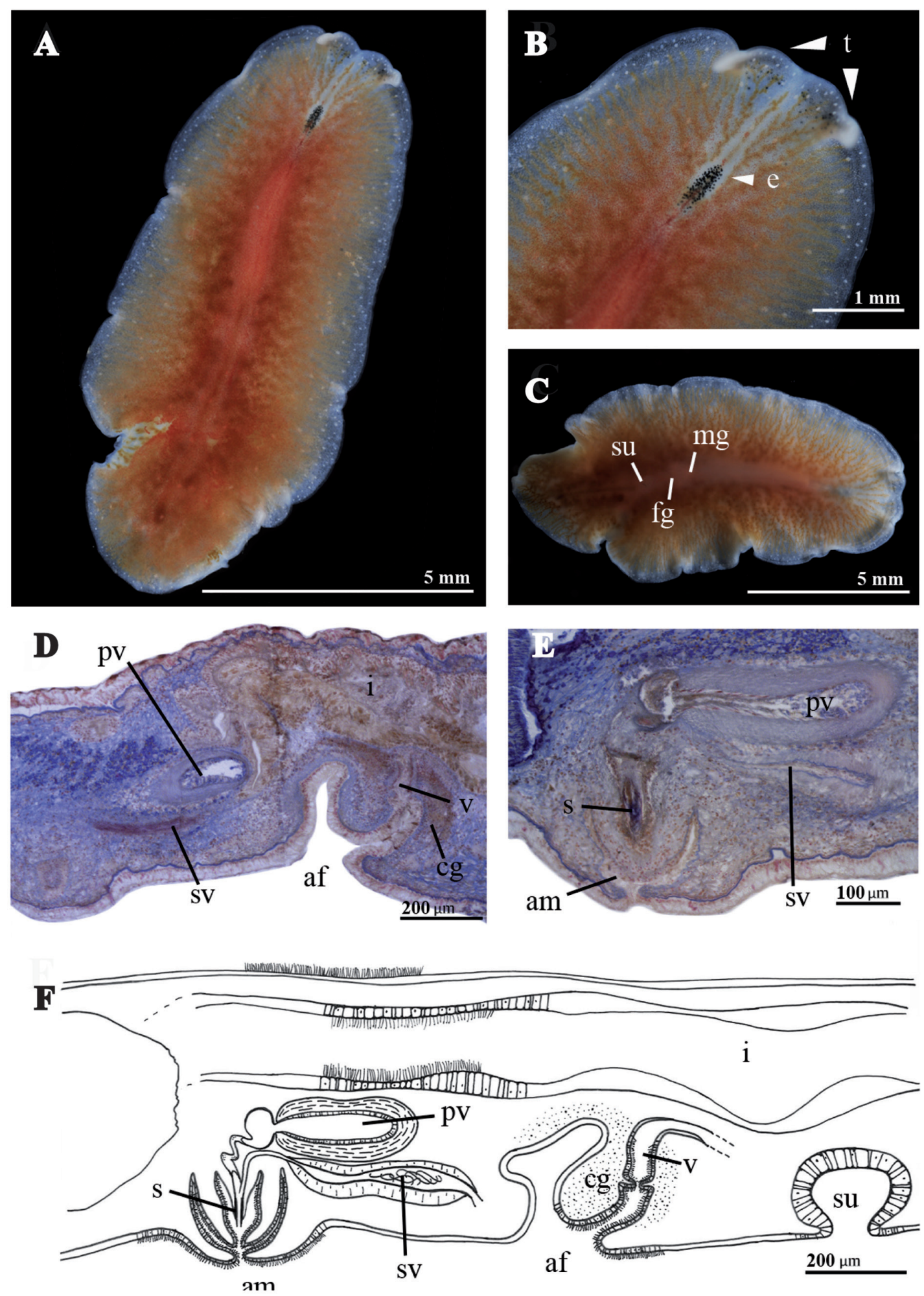

Fig. 6. Eurylepta cornuta var. melobesiarum (Schmidtlein, 1880) (RCCN). A. Whole live animal, dorsal view. B. Anterior region with eyes and tentacles (white arrows). C. Whole live animal, ventral view. D. Histological sagittal section of female copulatory organ. E. Histological sagittal section of male copulatory organ. F. Sagittal reconstruction of reproductive system. Abbreviations: see Material and methods. 


\section{Remarks}

The specimens of Cycloporus gabriellae captured in Cape Verde summarize the original description of C. gabriellae published by Marcus (1950), but differ externally and in coloration from C. gabriellae of Cabo Frio, Brazil (Bahia et al. 2014). This is the first record in the eastern region of the Atlantic Ocean for the species.

Genus Prostheceraeus Schmarda, 1859

Prostheceraeus moseleyi Lang, 1884

Figs $1 \mathrm{~A}, 7 \mathrm{C}$

\section{Material examined}

AZORES • 1 spec.; São Miguel Island; 3744'59.23" N, 25³7'12.12" W (Fig. 1A 1); 22 Jul. 2001; Leopoldo Moro leg.; RCCN.

\section{Distribution}

Tyrrhenian Sea (Lang 1884); Ria de Arosa, Spain (Noreña et al. 2015). This species has also been cited by DORIS (Données d'Observations pour la Reconnaissance et l'Identification de la faune et la flore Subaquatiques) for the English Channel and the North Sea, from the south of the United Kingdom to the Bay of Biscay (Spain) (http://doris.ffessm.fr/Especes/Prostheceraeus-moseleyi-Planaire-tachetee-716).

\section{New record}

São Miguel Island, Azores.

\section{Remarks}

The specimen collected in the Azores presents similar coloration to the specimen photographed by Wirtz \& Debelius (2003) and determined as Euryleptidae sp.

Family Anonymidae Lang, 1884

Genus Anonymus Lang, 1884

Anonymus ruber Cuadrado, Moro \& Noreña, 2017

Figs $1 \mathrm{C}, 7 \mathrm{~A}$

\section{Material examined}

CAPE VERDE • 3 specs; São Vicente Island, Baía das Gatas; 1654'09.33" N, 2454'25.25" W (Fig. 1C V2); May 2017; Leopoldo Moro leg.; RCCN.

\section{Distribution}

Tenerife Island, Canary Islands (type locality) (Cuadrado et al. 2017).

\section{New record}

Baía das Gatas, São Vicente Island, Cape Verde.

\section{Remarks}

Anonymous ruber is characterized by reddish brown tones, but some individuals from Cape Verde are paler and presented cream tonalities. From an anatomical (internal or external) and molecular point of view, the species found in Cape Verde does not differ from the species in the Canary Islands (Fig. 8). 
Family Pseudocerotidae Lang, 1884

Genus Pseudoceros Lang, 1884

Pseudoceros velutinus (Blanchard, 1847)

Figs 1C, 7D

Proceros velutinus Blanchard, 1847: 273, pl. 8, fig. 2; pl. 9, fig. 1.

Eurylepta velutina - Diesing 1850: 210; 1862: 548. — Stimpson 1857: 2. — Schmarda 1859: 26. — Diesing 1862: 548.

Pseudoceros velutinus - Lang 1884: 538-539, pl. 5, fig. 4.

\section{Material examined}

CAPE VERDE • 1 spec.; São Vicente Island, Baía das Gatas; 1654'09.33" N, 2454'25.25" W (Fig. 1C V2); 5 May 2017; Leopoldo Moro leg.; RCCN.

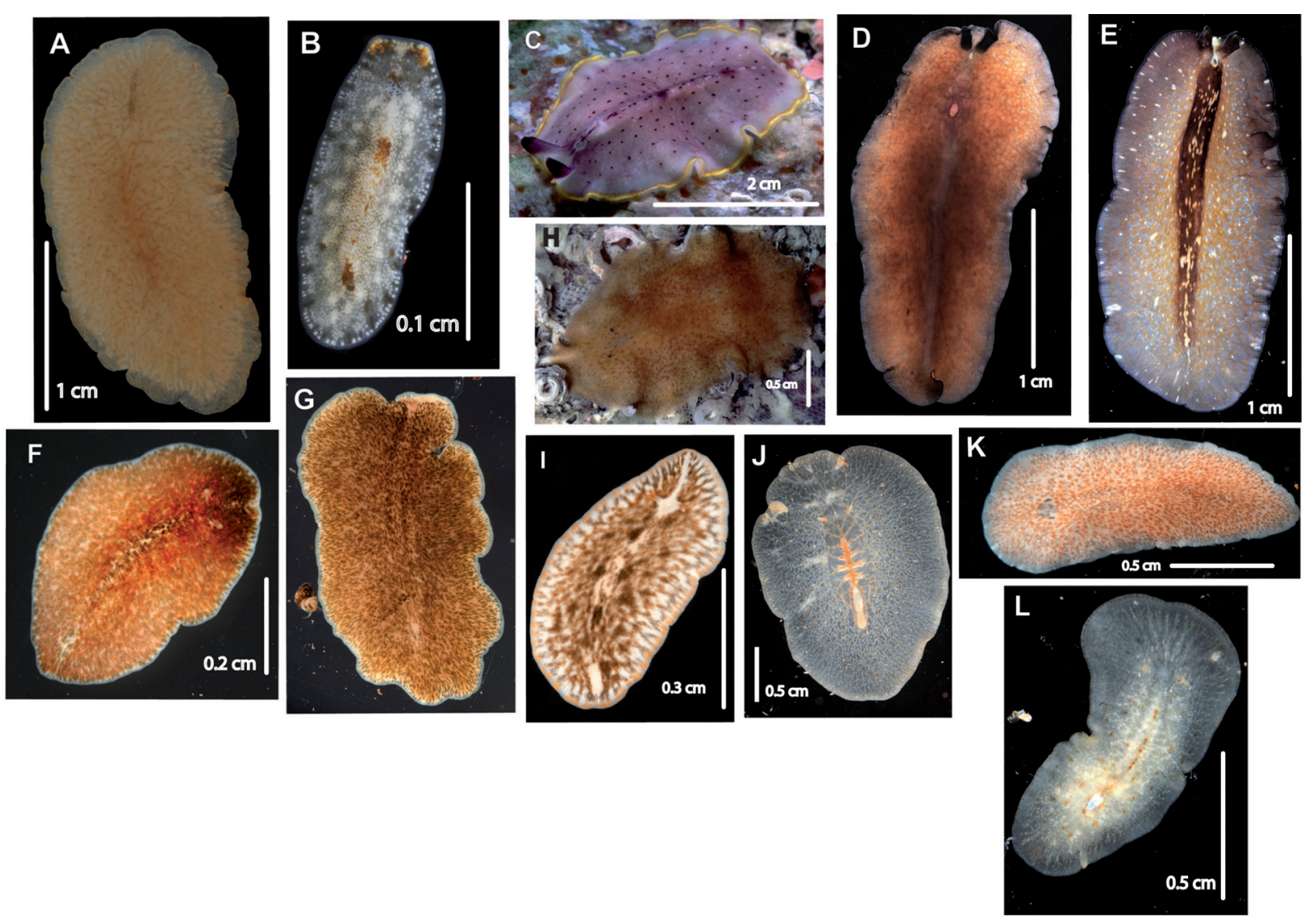

Fig. 7. A. Anonymus ruber Cuadrado, Moro \& Noreña, 2017 from Cape Verde. B. Cycloporus gabriellae Marcus, 1950 from Cape Verde. C. Prostheceraeus moseley Lang, 1884 from Cape Verde. D. Pseudoceros velutinus (Blanchard, 1847) (transmitted light) from Cape Verde. E. Monobiceros langi Faubel, 1984 from Cape Verde. F. Stylochus pilidium (Götte, 1881) from South Morocco. G. Stylochus pillidium (Götte, 1881) from Azores. H. Stylochus sp. from South Morocco. I. Stylochus neapolitanus (Delle Chiaje, 1841-1844) from Madeira. J. Planocera pellucida (Mertens, 1833) from Canary Islands. K. Discocelis tigrina (Blanchard, 1847) from Canary Islands. L. Gnesioceros sargassicola (Mertens, 1833) from Canary Islands. 


\section{Distribution}

Gulf of Genova, Italy (type locality) (Blanchard 1847); Suez Canal, Egypt (Palombi 1928); Rovigno, Croatia (Vàtova 1928); Canary Islands (Cuadrado et al. 2017).

\section{New record}

Baía das Gatas, São Vicente, Cape Verde.

\section{Remarks}

Pseudoceros velutinus is known for its velvety black pigmentation, but the coloration varies with transmitted or reflected light. Fig. 7D shows the appearance of $P$. velutinus with transmitted light.

Genus Monobiceros Faubel, 1984

Monobiceros langi Faubel, 1984

Figs $1 \mathrm{C}-\mathrm{D}, 7 \mathrm{E}$

Pseudoceros maximus Lang, 1884 (in part): 270-271, 543, pl. 30, fig. 17.

Monobiceros langi Faubel, 1984: 215.

\section{Material examined}

CAPE VERDE • 1 spec.; São Vicente Island, Baía das Gatas; 1654'09.33" N, 2454'25.24" W (Fig. 1C V2); May 2017; Leopoldo More leg.; RCCN.

MOROCCO • 3 specs; Sidi Ifni; 29²2'58.00" N, 10¹0'37.88"O (Fig. 1D M2); 2 Sep. 2016; Leopoldo Moro leg.; RCCN.

\section{Distribution}

Gulf of Naples, Italy (Lang 1884); Cádiz, Spain (Bahia et al. 2017); Crete, Greece (Bahia et al. 2017).

\section{New records}

Baía das Gatas, São Vicente Island, Cape Verde. Sidi Ifni, Morocco. These are the first records outside the Mediterranean Sea.

\section{Description}

Body oval and elongated sometimes pear-shaped, with wavy margins and thickened dorsal midline. Length $2.3 \mathrm{~cm}$. The background color varies with transmitted or reflected light. With reflected light, the dorsal surface is chocolate brown, speckled with white patches. Under transmitted light, the pigmentation looks milky brown with dark margins and a dark dorsal midline that delimited the characteristic bulge (Fig. 7E). Dorsal surface smooth. Tentacles formed by simple folds and cone-like in shape. Cerebral eyes form a single large rounded cluster behind the tentacles; frontal eyes scattered between the tentacles. Compact ruffled pharynx located directly behind the cerebral eyes.

Suborder Acotylea Lang, 1884

Superfamily Stylochoidea Poche, 1926

Family Stylochidae Stimpson, 1857

Genus Stylochus Ehrenberg, 1831

Stylochus pilidium (Götte, 1881)

Figs $1 \mathrm{C}-\mathrm{D}, 6 \mathrm{E}, \mathrm{I}, 7 \mathrm{~F}-\mathrm{G}$

Stylochopsis pilidium Götte, 1881: 189.

Planaria neapolitana - Götte 1878: 75-76. 
Stylochus pilidium - Götte 1882: 1-56, pls I-II. — Lang 1884: 320-321, 325, 329, 341-343, 351-353, 357, 401, pl. 36. fig. 19, pl. 37, figs 1, 16-17, 22.

\section{Material examined}

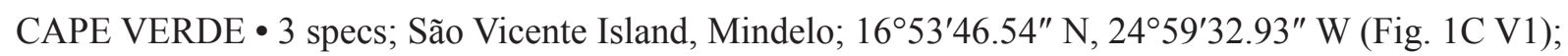
May 2017; Leopoldo More leg.; RCCN.

MOROCCO • 3 specs; Sidi Ifni; 29²2'58.00" N, 10¹0'37.88" W (Fig. 1D M2); 2 Sep. 2016; Leopoldo Moro leg.; RCCN.

\section{Distribution}

Gulf of Naples, Mediterranean Sea (type locality) (Götte 1881; Lang 1884; Lo Bianco 1888); Gulf of Venice (Bock 1925); Black Sea (Rzhepishevskii 1979); Vietnam (Dawydoff 1952); Somalia (Laidlaw 1903); Zanzibar (Meixner 1907).

\section{New records}

São Vicente Island, Cape Verde (Fig. 6E). Sidi Ifni, Morocco (Fig. 6I).

\section{Stylochus sp.}

Figs $1 \mathrm{~A}, 7 \mathrm{H}$

\section{Material examined}

AZORES • 1 spec.; São Miguel Island, Ponta Delgada; 3744'59.23" N, 25³7'12.12" W (Fig. 1A A1); 22 Jul. 2001; Leopoldo Moro leg.; RCCN.

\section{New record}

São Miguel Island, Azores. This is the first record for the genus Stylochus in the Azores. No molecular data.

\section{Stylochus neapolitanus (Delle Chiaje, 1841-1844)}

Figs 1D, 7I

Planaria neapolitana Delle Chiaje, 1841: vol. III: 133 (text); vol. V: 112 (description); pl. 109, figs 13$15,22$.

Stylochus neapolitanus - Lang 1884: 447-449, pl. 1, fig. 7.

\section{Material examined}

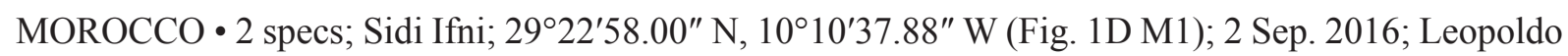
Moro leg.; RCCN.

\section{Distribution}

Western Mediterranean Sea, Sicily (type locality) (Delle Chiaje 1841); Naples, Italy (Lang 1884); Catalonia, Spain (Novell 2003); Mar Menor, Murcia, Spain (Marquina et al. 2014); Ría de Arousa, Galicia, Spain (Noreña et al. 2015); Cape Verde (Laidlaw 1906); Rufisque, Senegal (Palombi 1939).

\section{New record}

Sidi Ifni, Morocco. 
CUADRADO D. et al., New species and records from Macaronesia and Cape Verde

Family Planoceridae Lang, 1884

Genus Planocera Blainville, 1828

Planocera pellucida (Mertens, 1833)

Figs $1 \mathrm{~B}, 7 \mathrm{~J}$

Planaria pellucida Mertens, 1833: 8-13, pl. 1

Stylochus pellucidus - Ehrenberg 1836: 67. — Diesing 1850: 216. — Claparède 1861: 143. — Moseley 1877: 23.

Planocera pellucida - Örsted 1844: 48.

Gnesioceros pellucidus - Diesing 1862: 571.

\section{Material examined}

MADEIRA • 1 spec.; 3241'18.52" N, 1658'57.36" W (Fig. 1B); 2000; Leopoldo Moro leg.; RCCN.

\section{Distribution}

Atlantic Ocean, between Newfoundland and Ireland (type locality) (Mertens 1833); Pacific Ocean (Graff 1892; Woodworth 1894; Plehn 1896); Canary Islands (De Vera et al. 2009; Cuadrado et al. 2017); Vietnam (Dawydoff 1952); the North Sea (Prudhoe 1982); Japan (Kato 1938); the Mediterranean Sea (Lang 1879, 1884; Riedl 1959; Marquina et al. 2014); pelagic fauna of the Atlantic Ocean (Graff 1892; Plehn 1896); Cape Verde and Ascension islands (Plehn 1896; Laidlaw 1903);

\section{New record}

Madeira.

\section{Remarks}

Planocera pellucida, together with Pseudoceros wirtzi, Pseudoceros cf. maximus and Prostheceraeus giesbrechtii are the three polyclad species currently recorded for Madeira. As can be seen in Fig. 7J. The specimens of Planocera pellucida from Madeira do not differ molecularly from those captured in the Canary Islands.

Superfamily Leptoplanoidea Faubel, 1984

Family Discocelidae Laidlaw, 1903

Genus Discocelis Ehrenberg, 1836

Discocelis tigrina (Blanchard, 1847)

Figs $1 \mathrm{~B}, 7 \mathrm{~K}$

Polycelis tigrinus Blanchard, 1847: 271-272, pl. 8, fig. 1.

Leptoplana tigrina - Diesing 1850: 195; 1862: 527.

Elasmos tigrinus - Stimpson 1857: 3.

Discocelis tigrina - Lang 1884: 467-469, pl. 3, fig. 3; pl. 4, fig. 1; pl. 2, fig. 6.

\section{Material examined}

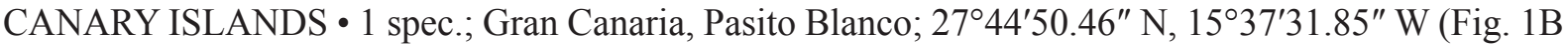
C1); 9 Aug. 2016; Leopoldo Moro leg.; RCCN. 


\section{Distribution}

Río de Oro peninsula, Western Sahara (Palombi 1939); Naples, Italy (Lang 1884); Catalonia, Spain (Novell 2003); Asturias, Spain (Marquina et al. 2014); Galicia, Spain (Noreña et al. 2015); Mauritania (Palombi 1939).

\section{New record}

Pasito Blanco, Gran Canaria, Canary Islands.

Family Gnesiocerotidae Marcus \& Marcus, 1966

Genus Gnesioceros Diesing, 1862

Gnesioceros sargassicola (Mertens, 1833)

Figs 1B, 7L

Planaria sargassicola Mertens, 1833: 13-14, pl. I, figs 4-6.

Stylochus Mertensi Diesing, 1850: 216.

Stylochus sargassicola - Ehrenberg 1836: 67. — Claparède 1861: 143.

Planocera sargassicola - Örsted 1844: 48.

Gnesioceros sargassicola - Diesing 1862: 571.

Gnesioceros Mertensi- Diesing 1862: 572.

Stylochus Mertensi - Moseley 1877: 23.

\section{Material examined}

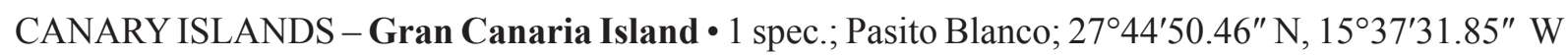
(Fig. 1B C1); 4 Jan. 2017; Leopoldo Moro leg.; RCCN. - Tenerife Island • 1 spec.; 28²4'35.71" N, 16²18'25.31" W (Fig. 1B C2); 7 Jun. 2011; Leopoldo Moro leg. RCCN.

\section{Distribution}

Bermuda Islands (Hyman 1939); Sargasso Sea, Caribbean Sea, Atlantic Ocean (Faubel 1983); Gulf of Mexico (Hyman 1954); Atlantic Ocean (Moseley 1877); Boa Vista Island, Cape Verde (Laidlaw 1903); Santa Marta, Colombia (Quiroga 2008); Netherlands, Puerto Rico, Florida, USA, Sargasso Sea, Atlantic Ocean (Marcus \& Marcus 1968).

\section{New records}

Pasito Blanco, Gran Canaria, and Tenerife, Canary Islands.

\section{Remarks}

Gnesioceros sargassicola was limited to the Antilles and the Caribbean Sea until the record of Laidlaw (1903) for the Cape Verde Islands. The new record of G. sargassicola for the Canary Islands shows a progressive 'colonisation' of the Atlantic east coast.

\section{Molecular analysis}

The main purpose of the $28 \mathrm{~S}$ analysis was to confirm the determinations made from the morphological study and verify the relationships among similar species.

The recovered topology by both trees, Bayesian Inference (BI) as well as Maximum Likelihood (ML) strongly supports the monophyly of the suborders Acotylea and Cotylea (Fig. 8; Acotylea: BPP (Bayesian 
posterior probabilities $)=1$ and $\mathrm{BS}$ (Bootstrap values of $\mathrm{ML}$ analysis $)=73$, Cotylea: $\mathrm{BPP}=0.98, \mathrm{BS}=$ 100).

Within Acotylea, the monophyly of Leptoplanoidea (BPP =1, BS =97) and Stylochoidea (BPP = 1, $\mathrm{BS}=73$ ) is well supported. Callioplana marginata Stimpson, 1857 considered within the superfamily Stylochoidea appears isolated with the highest support $(\mathrm{BS}=100)$.

As a sister group of Leptoplanoidea, there is a clade of species: Ilyella gigas (Schmarda 1859), Discocelis tigrina (Blanchard, 1847), Adenoplana evelinae Marcus, 1950, Amemiyaia pacifica Kato, 1944 and Phaenocelis medvedica Marcus, 1952 showing low support and not clearly grouped (Fig. 8).

The main group of Leptoplanoidea encloses the family Leptoplanidae, with the genera Leptoplana Ehrenberg, 1831 and Armatoplana Faubel, 1983, and the family Notoplanidae Marcus \& Marcus, 1966 with the genera Notoplana Laidlaw, 1903 and Notocomplana Faubel, 1983. Pseudostylochus Yeri \& Kaburaki, 1918 and Koinostylochus Faubel, 1983 appear together and belong to the family Pseudostylochidae Faubel, 1983.

Within Stylochoidea, four main clades are recovered: family Stylochidae with the genera Stylochus, Imogine Girard, 1853 and Paraplanocera Laidlaw, 1903 (see the Discussion); family Latocestidae Laidlaw, 1903 with Leptostylochus Bock, 1925 and Latocestus; family Hoploplanidae StummerTraunfels, 1933 with Hoploplana Laidlaw, 1902 and finally family Planoceridae with Paraplanocera Laidlaw, 1903 and Planocera. Callioplana marginata can be considered a sister group of Stylochoidea.

Within the suborder Cotylea, the families Cestoplanidae Lang, 1884, Pericelidae Laidlaw, 1902 and Anonymidae represented by the genera Cestoplana Lang, 1884 (BPP = 1, BS 100), Pericelis (BPP = 1, BS 100) and Anonymus (BPP =1, BS 100), respectively are presented as isolated groups. While Boninia Bock, 1923, Chromyella Correa, 1958 and Theama Marcus, 1949 form a well-supported group (BPP =1, $\mathrm{BS}=100$ ), although currently belonging to separate families and not specifically related to each other.

After Anonymidae, we find a well-supported branch $(\mathrm{BPP}=0.9, \mathrm{BS}=95)$ that encompasses the families Prosthiostomidae Lang, 1884, Euryleptidae and Pseudocerotidae. This branch is, in turn, divided into two main branches (both supported by maximum values: $\mathrm{BPP}=1, \mathrm{BS}=100$ ) where Prosthiostomidae is separated from Euryleptidae and Pseudocerotidae, families with a clear relation.

\section{Discussion}

After the present study and the results obtained, it is evident that the knowledge on polyclad biodiversity in Macaronesia is clearly uneven. Polyclads from Cape Verde, Madeira and Canary Islands are mostly well studied, while information from the Azores and Selvagens Islands is irregular. Consequently, a comparison of the biodiversity of the different archipelagos is biased, but not impossible.

The 6 new species of Cape Verde could currently be considered endemic from Cape Verde until new or future studies show an expansion of its distribution. On the other hand, from the 50 species considered in the present study, 31 belong to Cape Verde, of which 11 species are also present in the Canary Islands and 2 species in South Morocco. These species are mostly considered cosmopolitan: Thysanozoon brocchi, Cestoplana rubrocincta (Grube, 1850) and Planocera pellucida. Other species like Pseudobiceros wirtzi and Pseudoceros mororum are recorded from Madeira, Canary Islands and Cape Verde. Pseudoceros velutinus and Anonymus virilis Lang, 1884 show a known broad distribution along the Mediterranean (Tyler et al. 2006-2020). The four remaining species Anonymus ruber, Latocestus plehni Laidlaw, 1906, Cycloporus gabriellae and Pericelis cata, are currently only recorded for Canary Islands and also known for the coasts of Brazil. 


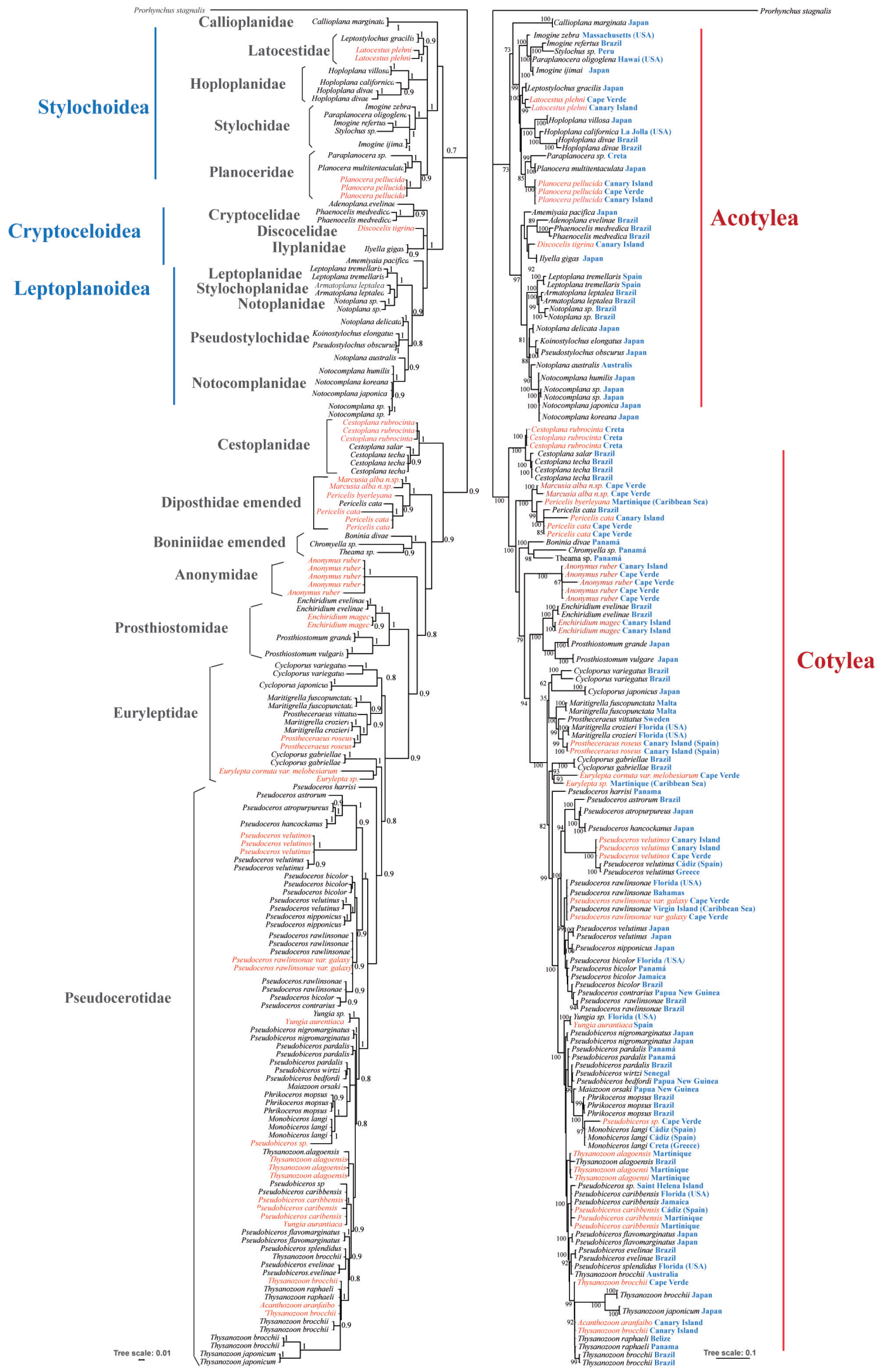


Stylochus neapolitanus is described for the Mediterranean and has also been recorded for Cape Verde by Laidlaw (1906). Considered by the same author as doubtful because according to this author the species of this genus (Stylochus) are difficult to distinguish (Laidlaw 1906: 707).

This group of common species shows Cape Verde as an independent archipelago with unique biological and ecological characteristics and therefore, fauna. Regardless, it is still under the influence of other regions. As such, our results confirm the hypotheses of Spalding et al. (2007) and Freitas et al. (2019) who propose Cape Verde as an independent archipelago outside of Macaronesia with its own ecological and biological history and as a specific hotspot (Freitas et al. 2019).

Most of the studied species of Cape Verde belong to the island of São Vicente (Laidlaw 1906) and only 9 species were collected in Boa Vista, Santo Antão and Santiago. In the present study, samples from the island of São Vicente were examined, but only two species coincide with those recorded by Laidlaw (1906).

The second best studied archipelago is the Canary Islands (Cuadrado et al. 2017). In the present study, Discocelis tigrina and Gnesioceros sargassicola are new records added to the biodiversity of the archipelago and the distribution of Pseudoceros mororum, to date limited to the island of Gran Canaria, has been extended to Tenerife.

While the focus of this study doesn't lie in the analysis of the Macaronesian species from a molecular point of view, such analyses were carried out to verify the previous morphological determination and to add another source of proof to the delimitation of new species.

The latest molecular analyses have contributed to improve the resolution of the systematics and configuration of families and superfamilies of the order Polycladida. The studies carried out by Aguado et al. (2016, 2017), Bahia et al. (2017), Dittmann et al. (2019), Kenny et al. (2019) and Litvaitis et al. (2019) are of particular relevance. As the last authors discuss the previous studies, we will mainly compare our results with their analyses. In general, the phylogenetic trees (both ML and BI) obtained in the present study show an almost identical topology at the family level to those presented by Litvaitis et al. (2019).

Regarding the newly sequenced and analysed material (Bordeaux in Fig. 8), Latocestus plehni, within Acotylea, shows the same close relationship with Leptostylochus gracilis Kato, 1934 as mentioned by Litvaitis et al. (2019), therefore we include the genus Leptostylochus together with Latocestus in the family Latocestidae.

The genus Notoplana certainly presents a problem in our analysis. While some species from Brazil (Notoplana sp.) appear within the family Notoplanidae, others from Japan are closely related to the family Stylochoplanidae Faubel, 1983. Finally, Notoplana australis (Laidlaw, 1904) is included within the family Notocomplanidae Litvaitis, Bolaños \& Quiroga, 2019. This shows the variety of the genus Notoplana, at least with respect to the $28 \mathrm{~S}$ gene. With new morphological analyses and the use of more molecular markers, perhaps we will obtain more satisfactory results to resolve the relationship of the genus Notoplana.

On the other hand, and within Leptoplanoidea, Pseudostylochus and Koinostylochus are considered synonymous and belong to the family Pseudostylochidae (Oya \& Kajihara 2020).

Fig. 8 (on the opposite page). Polycladida 28S rDNA Maximum Likelihood phylogenetic tree at the right and Bayesian Inference tree at the left. Species highlighted in bordeaux: own material. 
Planocera pellucida, regardless of the origin location (Canarias or Cape Verde) seems to represent the same species despite differences in populations and well framed within the family Planoceridae. The same happens with Discocelis tigrina, although there are differences between the populations of the Atlantic (Canary Islands) and the Mediterranean (Catalonia).

Within Cotylea, Cestoplana rubrocincta is included together with Cestoplana salar Marcus, 1949 and Cestoplana techa Du Bois-Reymond Marcus, 1957 within the family Cestoplanidae. Next, the family Diposthidae shows a clear relationship between the genera Pericelis and Marcusia, but in both analyses (ML and $\mathrm{BI}$ ) the two genera are clearly differentiated and confirmed as valid genera.

Anonimus ruber within Anonimidae, presents the same condition as Planocera pellucida (Acotylea), where no differences appear between the populations of the Canary Islands and Cape Verde.

Prostheceraeus roseus and Enchiridium magec, both species captured in the Canary Islands, are well defined and included within their respective families, Euryleptidae and Prosthiostomidae. On the other hand, Eurylepta cornuta var. melobesiarum shows clear differences with Eurylepta sp., an immature specimen from Martinique, possibly E. cornuta but could not be confirmed.

Within the family Pseudocerotidae the relationships are more complex. In general, the species of the genus Pseudoceros are well framed within a clade, while the rest of the genera appear scattered. Pseudobiceros Faubel, 1984, Thysanozoon Grube, 1840, Monobiceros, Phrikoceros Newman \& Cannon, 1996 and Yungia Lang, 1884 appear closely related and well separated from the genus Pseudoceros. The first three genera share a double male copulatory organ while in Phrikoceros and Yungia it is single. Monobiceros and Phrikoceros are grouped in a single clade in our analysis, but they are morphologically different.

Close relationships among diverse morphotypes are already mentioned by Lang (1884), which includes clearly different morphotypes under the species Pseudoceros maximum. According to Lang (1884) this species could present externally three coloration patterns: brown with dark striations (Form A; Lang 1884: pl. 9, fig 1), dark with white splatters (Form B; Lang 1884: pl. 9, fig. 2) or beige with lighter, rounded spots (Form C; Lang 1884: pl. 9, fig. 3). Internally, Pseudoceros maximus could present one (type a) or two (type b) male copulatory organs, both types with a single gonopore. Faubel (1984) separates both morphotypes into Pseudoceros maximus, with a male copulatory organ type a, and in Monobiceros langi with a type $\mathrm{b}$, but no reference to the coloration pattern of these two species is made.

As such, species with one of the different color patterns described for P. maximus by Lang (1884) are: Phrikoceros mopsus (Marcus, 1952) (form C, type a) and Pseudobiceros caribbensis Bolaños, Quiroga \& Litvaitis, 2007 (form A; type b, but with 2 gonopores) from the Caribbean. In our analysis, Phrikoceros mopsus and Monobiceros langi (form B, type b) appear together, while Pseudobiceros caribbensis appears grouped in a single isolated branch. These results indicate the close relationship between P. mopsus and M. langi, which seem to support the different morphotypes of Lang's P. maximus. Unfortunately, without sequences of Pseudoceros maximus (form A, type a) the resolution of the complex of species (or morphotypes) 'P. maximus' remains for a future study.

The species whose sequences were obtained from GenBank (NCBI) appear in the same positions described in other works (Bahia et al. 2017; Litvaitis et al. 2019) but some showcase new relationships that should be discussed.

Leptostylochus gracilis, which appears as closely related to Latocestus and Idioplana in Litvaitis et al. (2019), appears as a sister group to Latocestus in our analyses, a relationship that indicates a clear belonging to the family Latocestidae and not family Stylochidae. 
The Hawaiian Paraplanocera oligoglena (Schmarda, 1859) is found within Stylochidae and clearly related to Stylochus and Imogine, genera which present little differences from one another. These results indicate that Stylochus and Imogine are possibly one genus (Dittman et al.2019), to which the Hawaiian species belongs.

Amemiyaia pacifica does not seem to belong to the Cryptocelidae Laidlaw, 1903 as it appears in the results obtained by Litvaitis et al. (2019), but it is closely related to this family. Adenoplana evelinae, in comparison, appears in both analyses (ML and BI) within Cryptocelidae and not within Discocelidae, a fact that looks to corroborate the results of Bahia et al. (2017).

\section{Acknowledgments}

The authors thank Annie Machordom and Iván Acevedo for access to the facilities of the molecular biology laboratory of the National Museum of Natural Sciences and logistic support. We also thank Lourdes Alcaraz for her help and support during the investigations in this laboratory. Likewise, we thank María Valladolid and Manuela Gallardo for access and assistance provided in the histology laboratory of the National Museum of Natural Sciences. We cannot forget Christoph Bleidorn and Maite Aguado who contributed decisively to the financing of this study - thank you very much. We would like to thank the MIMAR project (Monitoring, control and mitigation of proliferation of marine organisms associated with human disturbances and climate change in the Macaronesian Region), co-financed by FEDER funds through the INTERREG V-A MAC program 2014-2020.

\section{References}

Aguado M.T., Grande C., Gerth M., Bleidorn C. \& Noreña C. 2016. Characterization of the complete mitochondrial genomes from Polycladida (Platyhelminthes) using next-generation sequencing. Gene 575: 199-205. https://doi.org/10.1016/j.gene.2015.08.054

Aguado M.T., Noreña C., Alcaraz L., Marquina D., Brusa F., Damborenea C., Almon B., Bleidorn C. \& Grande C. 2017. Phylogeny of Polycladida (Platyhelminthes) based on mtDNA data. Organisms Diversity \& Evolution 17: 767-778. https://doi.org/10.1007/s13127-017-0344-4

Bahia J. \& Schrödl M. 2016. Pseudobiceros wirtzi sp. nov. (Polycladida: Cotylea) from Senegal with revision of valid species of the genus. Zootaxa 4097: 101-117. https://doi.org/10.11646/zootaxa.4097.1.5

Bahia J., Padula V., Passeri Lavrado H. \& Quiroga S. 2014. Taxonomy of Cotylea (Platyhelminthes: Polycladida) from Cabo Frio, southeastern Brazil, with the description of a new species. Zootaxa 3873: 495-525. https://doi.org/10.11646/zootaxa.3873.5.3

Bahia J., Padula V. \& Schrödl M. 2017. Polycladida phylogeny and evolution: integrating evidence from 28S rDNA and morphology. Organisms Diversity \& Evolution 17: 653-678.

https://doi.org/10.1007/s13127-017-0327-5

Beauchamp P de. 1951. Turbellaries polyclades du Maroc et de Mauritanie. Bulletin de la Société des sciences naturelles [et physiques] du Maroc (1949) 39: 239-249.

Blanchard E. 1847. Recherches sur l'organisation des vers. Annales des Sciences naturelles. Zoologie 7: 87-128, 8: 119-149, 271-275. https://doi.org/10.5962/bhl.title.51506

Bock S. 1925. Papers from Dr. Th. Mortensen's Pacific Expedition 1914-16. XXVII. Planarians, Pt. IV. New stylochids. Videnskabelige meddelelser fra den Naturhistoriske forening i Kjöbenhavn 79: 97-184. https://doi.org/10.5962/bhl.title.82330 
Bulnes V., Faubel A. \& Park J.-K. 2005. Two new marine species from South Korea with remarks on the family Stylochidae (Acotylea, Polycladida, Plathelminthes). Journal of Natural History 39 (23): 2089-2107. https://doi.org/10.1080/00222930500081997

Castresana J. 2000. Selection of conserved blocks from multiple alignments for their use in phylogenetic analysis. Molecular Biology and Evolution 17: 540-552.

https://doi.org/10.1093/oxfordjournals.molbev.a026334

Chen H., Rangasamy M., Tan S.Y., Wang H. \& Siegfried B.D. 2010. Evaluation of five methods for total DNA extraction from western corn rootworm beetles. PLoS ONE 5: e11963.

https://doi.org/10.1371/journal.pone.0011963

Claparède E. 1861. Études anatomiques sur les annélides, turbellariés, opalines et grégarines observés dans les Hébrides. Memoires de la Société des physique et d'histoire naturelle de Genève 16 (4): 56-80, 124-148, 151-152. https://doi.org/10.5962/bhl.title.14795

Cuadrado C., Moro L.\& Noreña C. 2017. The Polycladida (Platyhelminthes) of the Canary Islands. New genus, species and records. Zootaxa 4312: 38-68. https://doi.org/10.11646/zootaxa.4312.1.2

Dawydoff C.N. 1952. Contribution à l'étude des invertebrés de la faune marina benthique de l'Indochine. Bulletin scientifique de la France et de la Belgique 39: 1-108.

De Nicolás J.P., Fernández-Palacios J.M., Ferrer F.J. \& Nieto E. 1989. Inter-island floristic similarities in the Macaronesian Region. Vegetatio 84: 117-125. https://doi.org/10.1007/BF00036512

De Vera A., Moro L., Bacallado J.J. \& Hernández F. 2009 [2008]. Contribución al conocimiento de la biodiversidad de policlados (Platyhelminthes, Turbellaria) en las Islas Canarias. Revista de la Academia Canaria de Ciencias 20: 45-59.

Available from https://mdc.ulpgc.es/cdm/ref/collection/racc/id/323 [accessed 18 Dec. 2020].

Delle Chiaje S. 1841. Descrizione e Notomia degli Animali Invertebrati della Sicilia Citeriore: Osservati Vivi negli Anni 1822-1830. Tom. IV. C. Batelli, Naples.

https://doi.org/10.5962/bhl.title.10031

Diesing C.M. 1850. Systema Helminthum. I. W. Braumüller, Vienna [Vindobonae]. https://doi.org/10.5962/bhl.title.46846

Diesing C.M. 1862 [1861]. Revision der Turbellarien. Abtheilung: Dendrocoelen. Sitzungsberichte der mathematischen naturwissenschaftlichen Classe der kaiserlichen Akademie der Wissenschaften zu Wien 44: 485-578. https://doi.org/10.5962/bhl.title.2108

Dittmann I.L., Cuadrado D., Aguado M.T., Noreña C. \& Egger B. 2019. Polyclad phylogeny persists to be problematic. Organisms Diversity \& Evolution 19: 585-608.

https://doi.org/10.1007/s13127-019-00415-1

Ehrenberg C.G. 1836. Über die Akalephen des rothen Meeres und der Organismus der Medusen der Ostsee. Abhandlungen der Königlichen Akademie der Wissenschaften zu Berlin 1835: 181-260. Available from https://www.biodiversitylibrary.org/item/94127\#page/269/mode/1up [accessed 18 Dec. 2020].

Faubel A. 1983. The Polycladida, Turbellaria; Proposal and establishment of a new system. Part I. The Acotylea. Mitteilungen aus dem Hamburgischen Zoologischen Museum und Institut 80: 17-121.

Faubel A. 1984. The Polycladida, Turbellaria; Proposal and establishment of a new system. Part II. The Cotylea. Mitteilungen aus dem Hamburgischen Zoologischen Museum und Institut 81: 189-259. 
Freitas R., Romeiras M., Silva L., Cordeiro R., Madeira P., González J.A., Wirtz P., Falcón J.M., Brito A., Floeter S.R., Afonso P., Porteiro F., Viera-Rodríguez M.A., Neto A.I., Haroun R., Farminhão J.N.M., Rebelo A.C., Baptista L.,Melo C.S., Martínez A., Núñez J., Berning B., Johnson M.E. \& Ávila S.P. 2019. Restructuring of the 'Macaronesia'biogeographic unit: a marine multi-taxon biogeographical approach. Scientific Reports 9: 15792. https://doi.org/10.1038/s41598-019-51786-6

Galán de Mera A., Pérez Latorre A.V. \& Vicente Orellana J.A. 2003. Relaciones fitogeográficas entre el suroccidente de la Península Ibérica y el Noroeste de África. Una propuesta de sectorización. Lagascalia 23: $27-51$.

Gamble FW. 1893. British Marine Turbellaria. Contributions to a knowledge of British marine Turbellaria. Quarterly Journal of Microscopical Science 34: 433-452.

Available from https://www.biodiversitylibrary.org/item/49113\#page/443/mode/1up [accessed 28 Jan. 2021].

Götte A. 1878. Zur Entwicklungsgeschichte der Seeplanarien. Zoologischer Anzeiger 1: 75-76. Available from https://www.biodiversitylibrary.org/item/95256\#page/89/mode/1up [accessed 18 Dec. 2020].

Götte A. 1881. Zur Entwicklungsgeschichte der Würmer. Zoologischer Anzeiger 4: 189-191. Available from https://www.biodiversitylibrary.org/item/36963\#page/203/mode/1up [accessed 18 Dec. 2020].

Götte A. 1882. Entwicklungsgeschichte von Stylochopsis pilidium n.sp. Untersuchungen zur Entwicklungsgeschichte der Würmer 1. Abhandlungen zur Bildungs- und Entwicklungs-geschichte des Menschen und der Thiere 8: 4-58.

Graff L. 1892. Pelagische Polycladen. Zeitschrift für wissenschaftliche Zoologie 55: 189-219. Available from https://www.biodiversitylibrary.org/item/138505\#page/199/mode/1up [accessed 18 Dec. 2020].

Hyman L.H. 1939. Some polyclads of the New England coast, especially of the Woods Hole region. The Biological Bulletin (Woods Hole) 76: 127-152. https://doi.org/10.2307/1537854

Hyman LH. 1953. The polyclad flatworms of the Pacific coast of North America. Bulletin of the American Museum of Natural History 100: 269-391. Available from http://hdl.handle.net/2246/1028 [accessed 28 Jan. 2021].

Hyman L.H. 1954. Free-living flatworms (Turbellaria) of the Gulf of Mexico. Fishery bulletin. United States Fish and Wildlife Service 55: 301-302. Available from https://www.biodiversitylibrary.org/item/22622\#page/321/mode/1up [accessed 18 Dec. 2020].

Kato K. 1938. On a pelagic polyclad, Planocera pellucida (Mertens) from Japan. Zoological Magazine (Japan) 50: 230-232.

Katoh K. \& Standley D.M. 2013. MAFFT multiple sequence alignment software version 7: improvements in performance and usability. Molecular Biology and Evolution 30: 772-780.

https://doi.org/10.1093/molbev/mst010

Kearse M., Moir R., Wilson A., Stones-Havas S., Cheung M., Sturrock S., Buxton S., Cooper A., Markowitz S., Duran C., Thierer T., Ashton B., Meintjes P. \& Drummond A. 2012. Geneious basic: an integrated and extendable desktop software platform for the organization and analysis of sequence data. Bioinformatics 28: 1647-1649. https://doi.org/10.1093/bioinformatics/bts199

Keferstein W. 1868. Beiträge zur Anatomie und Entwicklungsgeschichte einiger Seeplanarien von St. Malo. Abhandlungen der Königlichen Gesellschaft der Wissenschaften zu Göttingen, 14: 1-38. Available from https://www.biodiversitylibrary.org/item/109993\#page/26/mode/1up [accessed 28 Jan. 2021]. 
Kenny N.J., Noreña C., Damborenea C. \& Grande C. 2019. Probing recalcitrant problems in polyclad evolution and systematics with novel mitochondrial genome resources. Genomics 111: 343-355. https://doi.org/10.1016/j.ygeno.2018.02.009

Kunkel G. 1993. Die Kanarischen Inseln und ihre Pflanzenwelt. $3^{\text {rd }}$ Ed. Gustav Fischer Verlag, Stuttgart.

Laidlaw F.F. 1903. On the marine fauna of Zanzibar and British East Africa, from collections made by Cyril Crossland in the years of 1901 and 1902. - Turbellaria Polycladida. Part I. The Acotylea. Proceedings of the Zoological Society of London 1903 (2): 99-13. Available from https:/www.biodiversitylibrary.org/item/98617\#page/145/mode/1up [accessed 18 Dec. 2020].

Laidlaw F.F. 1906. On the marine fauna of the Cape Verde Islands, from collections made in 1904 by Mr. C. Crossland. - The polyclad Turbellaria. Proceedings of the Zoological Society of London 1906: 705719. Available from https://www.biodiversitylibrary.org/item/97669\#page/313/mode/1up [accessed 18 Dec. 2020].

Lang A. 1879. Untersuchungen zur vergleichenden Anatomie und Histologie des Nervensystems der Plathelminthen. I. Das Nervensystem der marinen Dendrocoelen. Mittheilungen aus der Zoologischen Station zu Neapel 1: 459-488. Available from https:/www.biodiversitylibrary.org/item/37435\#page/477/mode/1up [accessed 18 Dec. 2020].

Lang A. 1884. Die Polycladen (Seeplanarien) des Golfes von Neapel und der angrenzenden Meeresabschnitte. Eine Monographie. Fauna und Flora des Golfes von Neapel 11. Engelmann, Leipzig. https://doi.org/10.5962/bhl.title.10545

Letunic I. \& Bork P. 2019. Interactive Tree Of Life (iTOL) v4: recent updates and new developments. Nucleic Acids Research 47: 256-259. https://doi.org/10.1093/nar/gkz239

Litvaitis M.K, Bolaños D.M. \& Quiroga S.Y. 2010. When names are wrong and colours deceive: unravelling the Pseudoceros bicolor species complex (Turbellaria: Polycladida). Journal of Natural History 44: 829-845. https://doi.org/10.1080/00222930903537074

Litvaitis M.K., Bolaños D.M. \& Quiroga S.Y. 2019. Systematic congruence in Polycladida (Platyhelminthes, Rhabditophora): are DNA and morphology telling the same story? Zoological Journal of the Linnean Society 186: 865-891. https://doi.org/10.1093/zoolinnean/zlz007

Lo Bianco S. 1888. Notizie biologiche riguardanti specialmente il period di maturità sessuale degli animali del Golfo di Napoli. Mittheilungen aus der Zoologischen Station zu Neapel 8: 385-440. Available from https://www.biodiversitylibrary.org/item/37441\#page/395/mode/1 up [accessed 18 Dec. 2020].

Marcus E. 1950. Turbellaria Brasileiros (8). Boletim da Facultade de Philosophia, Sciencias e Letras, Universidade de São Paulo. Zoologia 15: 5-190.

https://doi.org/10.11606/issn.2526-4877.bsffclzoologia.1950.125192

Marcus E. 1952. Turbellaria Brasileiros (10). Boletim da Facultade de Philosophia, Sciencias e Letras, Universidade de São Paulo. Zoologia 17: 5-186.

https://doi.org/10.11606/issn.2526-4877.bsffclzoologia.1952.125189

Marcus E. \& Marcus Er. 1968. Polycladida from Curaçao and faunistically related regions. Studies on the Fauna of Curaçao and other Caribbean Islands 26: 1-133. Available from

https://repository.naturalis.n1/pub/506072 [accessed 18 Dec. 2020].

Marquina D., Osca D., Rodríguez J., Fernández-Despiau E. \& Noreña C. 2014. State of knowledge of the Acotylea (Polycladida, Platyhelminthes) from the Mediterranean coasts of Spain: new records and new species. Zootaxa 3780: 108-134. https://doi.org/10.11646/zootaxa.3780.1.4 
CUADRADO D. et al., New species and records from Macaronesia and Cape Verde

Médail F. \& Quézel P. 1999. The phytogeographical significance of S.W. Morocco compared to the Canary Islands. Plant Ecology 140: 221-244. https://doi.org/10.1023/A:1009775327616

Meixner A. 1907. Polycladen von der Somaliküste, nebst einer Revision der Stylochinen. Zeitschrift für wissenschaftiche Zoologie 88: 385-498. Available from

https://www.biodiversitylibrary.org/item/138612\#page/405/mode/1up [accessed 18 Dec. 2020].

Mertens H. 1833. Untersuchungen über den inneren Bau verschiedener in der See lebender Planarien. Mémoires del'Académie impériale des Sciences de Saint Pétersbourg. $6^{\text {ème }}$ série, Sciences mathématiques, physiques et naturelles 2: 3-17. Available from https://www.biodiversitylibrary.org/item/247344\#page/13/mode/1up [accessed 18 Dec. 2020].

Moseley H.N. 1877. On Stylochus Pelagicus, a new species of pelagic planarian, with notes on other pelagic species, on the larval forms of Thysanozoon, and of a gymnosomatous pteropod. Microscopical Journal 17: 23-32.

Müller O.F. 1776. Zoologiae Danicae Prodromus, seu Animalium Daniae et Norvegiae Indigenarum Characteres, Nomina, et Synonyma Imprimis Popularium. Hallageriis, Copenhagen [Havniae]. https://doi.org/10.5962/bhl.title.13268

Myers N., Mittermeier R.A., Mittermeier C.G., da Fonseca G.A.B. \& Kent J. 2000. Biodiversity hotspots for conservation priorities. Nature 403: 853-858. https://doi.org/10.1038/35002501

Noreña C., Rodríguez J., Pérez J. \& Almon B. 2015. New Acotylea (Polycladida, Platyhelminthes) from the east coast of the North Atlantic Ocean with special mention of the Iberian littoral. Zootaxa 4039: 157-172. https://doi.org/10.11646/zootaxa.4039.1.7

Novell C. 2003. Contribució al coneixement dels turbel-laris policlàdides del litoral català. $\mathrm{Ph}$ Thesis, University of Barcelona, Spain. Available from http://hdl.handle.net/10803/781 [accessed 18 Dec. 2020].

Örsted A.S. 1844. Entwurfeiner systematischen Einteilung und speciellen Beschreibung der Plattwuermer auf microscopische Untersuchungen gegruendet. I. Fam. Cryptocoela, 2. Fam Dendrocoela, 3. Fam. Rhabdocoela. J.C. Scharling, Copenhagen.

Oya Y. \& Kajihara H. 2020. Molecular phylogenetic analysis of Acotylea (Platyhelminthes: Polycladida). Zoological Science 37: 271-279. https://doi.org/10.2108/zs190136

Palombi A. 1928. Report on the Turbellaria. Zoological results of the Cambridge Expedition to the Suez Canal. 1924. Transactions of the Zoological Society of London 22: 579-630.

Palombi A. 1939. Turbellari del Sud Africa. Policladi di East London. Archivio zoologico italiano 28: 123-149.

Plehn M. 1896. Neue Polycladen, gesammelt von Herrn Kapitän Chierchia bei der Erdumschiffung der Korvett Vettor Pisani, von Herrn Prof. Dr. Kükenthal im nordlichem Eismeer und von Herrn Prof Dr. Semon in Java. Jenaische Zeitschrift für Naturwissenschaft 30: 137-181. Available from https://www.biodiversitylibrary.org/item/43546\#page/147/mode/1up [accessed 18 Dec. 2020].

Prudhoe S. 1982. Polyclad turbellarians from the southern coasts of Australia. Records of the South Australian Museum 18: 361-384. Available from https://www.biodiversitylibrary.org/item/127010\#page/380/mode/1up [accessed 18 Dec. 2020].

Prudhoe S. 1989. Polyclad turbellarians recorded from African waters. Bulletin of the British Museum of Natural History 55: 47-96. Available from

https://www.biodiversitylibrary.org/item/125484\#page/55/mode/1up [accessed 28 Jan. 2021]. 
Quiroga S.Y. 2008. Systematics and Taxonomy of Polyclad Flatworms with a special emphasis on the morphology of the nervous system. Ph Thesis, University of New Hampshire, USA. Avalilable from http://search.proquest.com/docview/304525403 [accessed 18 Dec. 2020].

Riedl R. 1959. Turbellarien aus submarinen Höhlen. 3. Seriata und Neorhabdocoela. Ergebnisse der Österreichischen Tyrrhenia-Expedition 1952. Teil IX. Pubblicazioni della Stazione zoologica di Napoli Suppl. 30: 305-332.

Rivas-Martínez S. 2009. Ensayo Geobotánico Global sobre la Macaronesia. Series Monograficas 78. Instituto de Estudios Canarios, La Laguna.

Ronquist F., Teslenko M., van der Mark P., Ayres D.L., Darling A., Höhna S., Larget B., Liu L., Suchard M.A. \& Huelsenbeck J.P. 2012. MrBayes 3.2: efficient Bayesian phylogenetic inference and model choice across a large model space. Systematic Biology 61: 539-542.

https://doi.org/10.1093/sysbio/sys029

Rzhepishevskii J.K. 1979. Acorn barnacles eating away by Stylochus pilidium. Biologiya Morya 48: $23-28$.

Salas M. \& Naranjo A. 2015. Singularidades de la región macaronésica. In: Santamarta J.C. \& Naranjo J. (coords) Restauración de la Cubierta Vegetal y Espacios Degradados en la Región de la Macaronesia: 37-70. Colegio de Ingenieros de Montes, Madrid.

Schmarda L.K. 1859. Neue wirbellose Thiere beobachtet und gesammelt auf einer Reise um die Erde 1853 bis 1857. Bd I: Neue Turbellarien, Rotatorien und Anneliden. W. Engelmann, Leipzig. https://doi.org/10.5962/bhl.title.85313

Spalding M.D., Fox H.E., Allen G.R., Davidson N., Ferdana Z.A., Finlayson M., Halpern B.S., Jorge M.A., Lombana A., Lourie S.A., Martin K.D., McManus E., Molnar J., Recchia C.A. \& Robertson J. 2007. Marine ecoregions of the world: a bioregionalization of coastal and shelf areas. Bioscience 57: 573-583. https://doi.org/10.1641/B570707

Stimpson W. 1857. Prodromus descriptionis animalium evertebratorum, quae in Expeditione ad Oceanum Pacificum Septentrionalem, Johanne Rodgers Duce a Republica Federata missa, observavit et descripsit. Pars I, Turbellaria Dendrocoela. Proceedings of the Academy of Natural Sciences of Philadelphia 9: 19-31. https://doi.org/10.5962/bhl.title.51447

Sunding P. 1979. Origins of the Macaronesia flora. In: Bramwell D. (ed) Plants and Islands: 13-40. Academic Press, London.

Thompson W. 1845. Additions to the Fauna of Ireland, including descriptions of some apparently new species of Invertebrata. The Annals and Magazine of Natural History 15: 308-322.

https://doi.org/10.1080/037454809495331

Trifinopoulos J., Nguyen L.T., von Haeseler A. \& Minh B.Q. 2016. W-IQ-TREE: a fast online phylogenetic tool for maximum likelihood analysis. Nucleic Acids Research 44: 232-235.

https://doi.org/10.1093/nar/gkw256

Tyler S., Artois T., Schilling S., Hooge M. \& Bush L.F. (eds). 2006-2020. World List of turbellarian worms: Acoelomorpha, Catenulida, Rhabditophora. Available from http://www.marinespecies.org/turbellarians [accessed 31 Aug. 2020].

Vàtova A. 1928. Compendis della flora e fauna del Mare Adriatico presso Rovigno con la distribuzione geografica delle species bentoniche. Memorie Reale Comitato Talassografico Italiano, Venezia, Italy 143: 154-174. 
CUADRADO D. et al., New species and records from Macaronesia and Cape Verde

Wirtz P. 1994. Underwater Guide Madeira - Canary Islands - Azores Fishes. English/German. Nagelschmid Verlag, Stuttgart.

Wirtz P. \& Debelius H. 2003. Mediterranean and Atlantic Invertebrate Guide. ConchBooks, Hackenheim.

Woodworth W.M. 1894. Report on the Turbellaria (Albatross-Report 9). Bulletin of the Museum of Comparative Zoology at Harvard College 25: 49-52. Available from

https://www.biodiversitylibrary.org/item/95212\#page/69/mode/1up [accessed 18 Dec. 2020].

Manuscript received: 22 May 2020

Manuscript accepted: 10 December 2020

Published on: 24 February 2021

Topic editor: Rudy Jocqué

Desk editor: Pepe Fernández

Printed versions of all papers are also deposited in the libraries of the institutes that are members of the EJT consortium: Muséum national d'histoire naturelle, Paris, France; Meise Botanic Garden, Belgium; Royal Museum for Central Africa, Tervuren, Belgium; Royal Belgian Institute of Natural Sciences, Brussels, Belgium; Natural History Museum of Denmark, Copenhagen, Denmark; Naturalis Biodiversity Center, Leiden, the Netherlands; Museo Nacional de Ciencias Naturales-CSIC, Madrid, Spain; Real Jardín Botánico de Madrid CSIC, Spain; Zoological Research Museum Alexander Koenig, Bonn, Germany; National Museum, Prague, Czech Republic. 